\title{
Bypassing Glutamic Acid Decarboxylase 1 (Gad1) Induced Craniofacial Defects with a Photoactivatable Translation Blocker Morpholino
}

Matthew J. O’Connor, ${ }^{\dagger}$ Lindsey L. Beebe, ${ }^{\ddagger}$ Davide Deodato, ${ }^{\dagger}$ Rebecca E. Ball, ${ }^{\S}$ A. Tyler Page, ${ }^{\S}$ Ariel J. VanLeuven, ${ }^{\S}$ Kyle T. Harris, ${ }^{\perp}$ Sungdae Park, ${ }^{\ddagger}$ Vani Hariharan, ${ }^{\S}$ James D. Lauderdale, ${ }^{*},{ }^{\prime}, \|$ and Timothy M. Dore ${ }^{*, \dagger, \perp_{(1)}}$

${ }^{\dagger}$ New York University Abu Dhabi, PO Box 129188, Abu Dhabi, United Arab Emirates

${ }^{\ddagger}$ Department of Genetics, University of Georgia, Athens, Georgia 30602, United States

${ }^{\S}$ Department of Cellular Biology, University of Georgia, Athens, Georgia 30602, United States

"Neuroscience Division of the Biomedical and Health Sciences Institute, Athens, Georgia 30602, United States

${ }^{\perp}$ Department of Chemistry, University of Georgia, Athens, Georgia 30602 United States

Supporting Information

ABSTRACT: $\gamma$-Amino butyric acid (GABA) mediated signaling is critical in the central and enteric nervous systems, pancreas, lungs, and other tissues. It is associated with many neurological disorders and craniofacial development. Glutamic acid decarboxylase (GAD) synthesizes GABA from glutamate, and knockdown of the gadl gene results in craniofacial defects that are lethal in zebrafish. To bypass this and enable observation of the neurological defects resulting from knocking down $\mathrm{gad} 1$ expression, a photoactivatable morpholino oligonucleotide (MO) against gad1 was prepared by cyclization with a photocleavable linker rendering the MO inactive. The cyclized MO was stable in the dark and toward degradative enzymes and was completely linearized upon brief exposure to $405 \mathrm{~nm}$ light. In the course of investigating the function of the ccMOs in zebrafish, we discovered that zebrafish possess paralogous gad1 genes, gadla and gad1b. A gad1b MO injected at the 1-4 cell stage caused severe morphological defects in head development, which could be bypassed, enabling the fish to develop normally, if the fish were injected with a photoactivatable, cyclized gad1b MO and grown in the dark. At 1 day post fertilization (dpf), light activation of the gadlb MO followed by observation at 3 and $7 \mathrm{dpf}$ led to increased and abnormal electrophysiological brain activity compared to wild type animals. The photocleavable linker can be used to cyclize and inactivate any MO, and represents a general strategy to parse the function of developmentally important genes in a spatiotemporal manner.

KEYWORDS: Glutamic acid decarboxylase, $\gamma$-amino butyric acid, GABAergic signaling, photoactivated morpholino, (8-bromo-7-hydroxyquinolin-2-yl)methyl, (8-cyano-7-hydroxyquinolin-2-yl)methyl

\section{INTRODUCTION}

$\gamma$-Amino butyric acid (GABA) mediated signaling is important in a number of neural and non-neural tissues in the vertebrate. Best known as an inhibitory neurotransmitter in the central nervous system (CNS), disruption in GABAergic signaling is associated with several neurological disorders, including epilepsy, ${ }^{1-3}$ schizophrenia, ${ }^{4-7}$ autism, ${ }^{8}$ spastic quadriplegic cerebral palsy $1,{ }^{9}$ and stiff-person syndrome. ${ }^{10}$ Outside of the CNS, GABA and GABAergic signaling have been reported in the enteric nervous system ${ }^{11-14}$ and for tissues including the pancreas ${ }^{15,16}$ and lungs, ${ }^{17}$ among others. ${ }^{18}$ GABAergic signaling in the lungs plays a critical role in asthma, ${ }^{17}$ and disruption of GABAergic signaling in the pancreas appears to be causal for insulin-dependent diabetes mellitus. ${ }^{19-21}$

GABAergic signaling has also been implicated in craniofacial development in mammals. GABA is synthesized from glutamic acid by a reaction catalyzed by the enzyme glutamic acid decarboxylase (GAD, IUBMB Enzyme Nomenclature EC 4.1.1.15). ${ }^{22}$ In mammals, the majority of GAD protein exists as two molecularly distinct forms with molecular weights of 67 and $65 \mathrm{kDa}$, known as $\mathrm{GAD}_{67}$ and $\mathrm{GAD}_{65}$, which are encoded by the GAD1 and GAD2 genes, respectively. ${ }^{23,24}$ Whereas both enzymes make GABA from glutamate, they are found in different subcellular locations and at different expression levels in the same tissue, suggesting that each enzyme contributes differently to cell and neuron function. ${ }^{25-31} G A D$ genes are also expressed in juveniles and adults, which indicates important roles in neuronal function and developmental processes. ${ }^{25,32-34}$

Received: $\quad$ May 9, 2018

Accepted: September 10, 2018

Published: September 10, 2018 
Because $\mathrm{GAD}$ converts an excitatory neurotransmitter into an inhibitory one, its function (or mis-function) has tremendous implications in the regulation of the nervous system. During development in mice and humans, loss-of-function mutations in the $G A D 1$ gene, but not $G A D 2$, or in the $G A B A_{A}$ receptor, beta 3 (GABRB3) subunit have been reported to result in oral clefts (e.g., cleft lip and cleft palate), indicating that GABAergic signaling through $\mathrm{GABA}_{\mathrm{A}}$ is required for normal palate development in mammals. ${ }^{35-40}$

We are studying the role of GABAergic signaling in the developing zebrafish, with emphasis on the CNS. Zebrafish are an important and widely used model system for studying normal and abnormal physiology of vertebrates, especially embryonic development. Control of gene expression in the zebrafish is an invaluable tool for studying physiological processes. ${ }^{41-43}$ Genes important to development often have multiple functions at different life cycle stages. Mutations or techniques that interfere with early gene function often preclude the study of later functions. Further, irreversible changes to the genome made through knockout or transgenic organisms can result in compensation or embryonic lethality. An efficient method for manipulating gene expression in a spatiotemporal fashion would be a useful tool for investigating stage or tissue-specific roles of developmental genes.

In zebrafish, gene function can be disrupted by injecting embryos prior to the 16-cell stage with synthetic oligonucleotides called morpholino oligonucleotides (MOs), ${ }^{44}$ which contain DNA bases linked through a backbone consisting of phosphorodiamidates and morpholine. The difference in structure renders the MO resistant to nucleases, while still being able to hybridize to complementary mRNA sequences with high affinity and specificity. Depending on whether the MO binds to intron/exon sequences or near the start codon, RNA splicing or translation is blocked. The resulting gene silencing can last up to 4 days. ${ }^{44}$ MOs are incredibly important for genetic studies in zebrafish. ${ }^{45}$

Standard MOs induce global and immediate gene silencing in zebrafish, which limits their experimental utility. A photoactivatable MO provides control over the timing and location of gene silencing, enabling the study of the role of a gene's expression at different stages of embryonic development. Photoactivatable negatively charged peptide nucleic acids (ncPNAs) and oligonucleotides have also been used to knock down gene expression in zebrafish, ${ }^{46-48}$ but MOs are more widely used in this important model organism. The first strategy reported for regulating the action of MOs in zebrafish with light used a hairpin linker ${ }^{49}$ that hybridized an inhibitor strand to the MO to inactivate it. ${ }^{50,51}$ Photolysis of the linker enabled dissociation of the MO from the inhibitor, releasing it to find its mRNA target. If the photocleaving element is (8-bromo-7hydroxyquinolin-2-yl)methyl (BHQ), ${ }^{52,53}$ then two-photon excitation (2PE) activates the MO. ${ }^{51}$ PhotoMorphs use RNA as the inhibitor strand, which is photochemically cleaved into two pieces that bind poorly to the MO strand. ${ }^{54}$ Placing the photocleavage site in the middle of an MO strand enables destruction of the MO with light, leading to activation of gene expression at different time points in development. ${ }^{55}$ The bases on an MO strand can be directly photocaged with photoremovable protecting groups (PPGs), which blocks hybridization with the target mRNA, although the technique requires at least four PPGs to be distributed on the MO strand to prevent premature binding of the MO to the mRNA. ${ }^{56}$
To eliminate the need for an inhibitor strand and ease of synthesis, Chen et al. created a caged cyclic morpholino (ccMO) against no tail-a $($ ntla $){ }^{57}$ Cyclization of the MO through a photocleavable linker to generate a ccMO prevents the $\mathrm{MO}$ from binding to its mRNA target (Figure 1). A dimethoxyni-
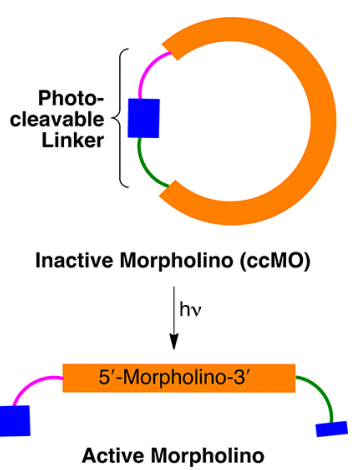

Figure 1. Photoactivation of a caged, cyclic morpholino (ccMO).

trobenzyl (DMNB) PPG mediates the photocleavage of the linker. Tang et al. reported a ccMO against $\beta$-catenin- 2 and $n t l$ using a linker comprised of a nitrophenethyl (NPE) PPG. ${ }^{58}$ Subsequently, Chen and Deiters reported wavelength selective activation of ccMOs against ntla, spade tail (spt), and floating head ( $\mathrm{flh}$ ) using nitrobenzyl (NB) and diethylaminocoumarin (DEACM) based linkers for short $(365 \mathrm{~nm})$ and longwavelength $(470 \mathrm{~nm}) \mathrm{MO}$ activation, respectively. ${ }^{59}$ Dmochowski et al. reported a ruthenium-based photolinker, RuBEP, for ccMOs against chordin (chd) and $n t l$ that can be activated at $450 \mathrm{~nm}^{60}$

We prepared ccMOs against the gad 1 and $\operatorname{gad} 2$ genes using a variation on Chen's linker design that employs our quinolinebased PPGs BHQ and (8-cyano-7-hydroxyquinolin-2-yl)methyl (CyHQ), 52,53,61 and demonstrated their use in conditionally manipulating gad gene function in the developing zebrafish embryo (see Methods for genetic nomenclature used in this report). Using BHQ and CyHQ expands the number of PPGs that can be used to prepare ccMOs activated with rapid photolysis kinetics $(<1 \mu$ s time scale) using low intensity light to minimize phototoxicity. Further, BHQ and CyHQ can be photolyzed through two-photon excitation (2PE), which would enable ccMO activation using deeply penetrating IR wavelengths. In the course of investigating the function of the ccMOs in zebrafish, we discovered that zebrafish possess paralogous gad1 genes (VanLeuven, A. J.; Ball, R. E.; Gunderson, C. E.; Lauderdale, J. D., submitted). Other fish species have two gad1 genes, designated as gadla and $\operatorname{gad} 1 b$, and a single gad 2 gene. $^{62-64}$ In zebrafish, gadla is located on chromosome 9, gad $1 b$ on chromosome 6, and gad2 on chromosome 24 (VanLeuven, A. J.; Ball, R. E.; Gunderson, C. E.; Lauderdale, J. D., submitted). Our gad MOs are designed to bind to the translation start sites of their respective transcript units. The gad1 MO is directed against gad 1b, which is broadly expressed in the developing zebrafish CNS. ${ }^{25,65-67}$

\section{RESULTS AND DISCUSSION}

Preparation of ccMOs. Two versions of the photocleavable linker were prepared: one from the BHQ PPG and the other from CyHQ. The BHQ-based linker 1a was prepared from the previously reported benzenesulfonate-protected BHQ derivative $\mathbf{5}$ (Scheme 1). ${ }^{51}$ The hydroxyl group in $\mathbf{5}$ was activated with 
Scheme 1. Synthesis of BHQ Linker $1 \mathrm{a}^{a}$

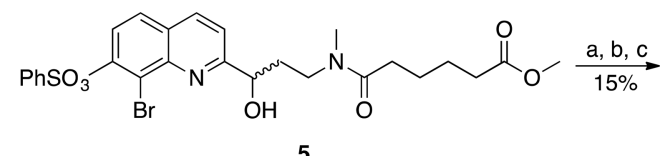<smiles>CNCCN(C)C(=O)O[C@H](CCN(C)C(=O)CCCCC(=O)O)c1ccc2ccc(O)c(Br)c2n1</smiles><smiles>CN(CCN(C)C(=O)O[C@H](CCN(C)C(=O)CCCCC(=O)O)c1ccc2ccc(O)c(Br)c2n1)C(=O)CCl</smiles><smiles>CN(CC[C@@H](OC(=O)N(C)CCN([14CH3])C(=O)[123I])c1ccc2ccc(O)c(Br)c2n1)C(=O)CCCCC(=O)ON1C(=O)CCC1=O</smiles>

${ }^{a}$ Reagents and conditions: (a) carbonyl diimidazole, $\mathrm{CH}_{2} \mathrm{Cl}_{2}, 15 \mathrm{~min}$; (b) $N, N^{\prime}$-dimethylethylene-diamine, $\mathrm{CH}_{2} \mathrm{Cl}_{2}, 0{ }^{\circ} \mathrm{C}, 15 \mathrm{~min}$; (c) acetonitrile/0.4 N NaOH(aq) (1:1), 12 h; (d) chloroacetyl chloride, DIEA, $15 \mathrm{~min}$, then TFA, $\mathrm{H}_{2} \mathrm{O}, 12 \mathrm{~h}$; (e) disuccinimidyl carbonate, pyridine, $\mathrm{CH}_{3} \mathrm{CN}, 12 \mathrm{~h}$.

carbonyl diimidazole and subsequently treated with $N, N^{\prime}$ dimethylethylene-diamine to extend the chain. Treatment with base removed the benzenesulfonate and hydrolyzed the methyl ester to give the acid 6 . The free secondary amine of 6 was acylated with chloroacetyl chloride to provide 7 , whose carboxylic acid could be activated for coupling to the MO with disuccinimidyl carbonate, providing $\mathbf{1 a}$.

Linker $\mathbf{1 b}$ was prepared from $\mathrm{CyHQ}^{61,68}$ by first protecting the phenol with a MEM group to give 8 , which was oxidized with selenium dioxide to aldehyde 9 (Scheme 2). An indiummediated Barbier reaction with allyl bromide produced homoallylic alcohol 10, whose alkene could be oxidatively cleaved with osmium tetroxide to aldehyde 11. This aldehyde was too unstable in air to be isolated so it was immediately reductively aminated to 12 , which was not purified, but quickly reacted with methyl adipoyl chloride to afford methyl ester 13. A similar method as described for 1a was used to convert 13 into 1b. A three-step sequence to grow a second arm of the linker from alcohol 13 provided 14. Trifluoroacetic acid removed the MEM group from the phenol and hydrolyzed the methyl ester, which could be converted to the succinimidyl ester $\mathbf{1 b}$ for coupling to a MO.

BHQ- and CyHQ-caged MOs against gad1b 4a-1 and 4b-1 and gad $2 \mathbf{4 b}-\mathbf{2}$, respectively, were prepared from their respective linkers $\mathbf{1 a}$ and $\mathbf{1 b}$ (Scheme 3 ). Linker $\mathbf{1 a}$ or $\mathbf{1} \mathbf{b}$ was coupled to the 5 -amine functionalized end of gad $1 b$ MO 2 through displacement of the succinimidyl ester in sodium borate buffer ( $\mathrm{pH}$ 8.5). After desalting, 3a-1, 3b-1, or $\mathbf{3 b - 2}$ was cyclized by reducing the disulfide bond in situ with tris(2-carboxyethyl)phosphine (TCEP) to the sulfhydryl, which displaced the chloride on $\mathbf{3 a - 1}, \mathbf{3 b}-\mathbf{1}$, or $\mathbf{3 b}-\mathbf{2}$ to form the BHQ- or CyHQ-
Scheme 2. Synthesis of CyHQLinker $1 b^{a}$

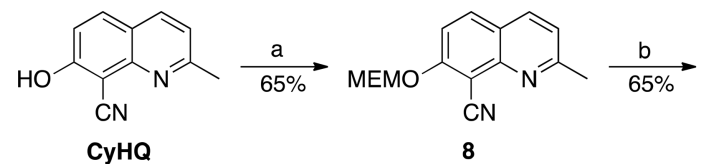

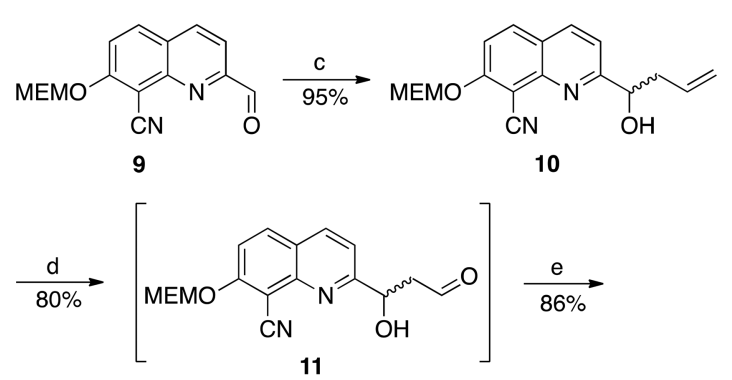<smiles>COc1ccc2ccc(CCCNCCC(O)C(C)C)nc2c1C#N</smiles><smiles>COC(=O)CCCCC(=O)N(C)CC[C@H](O)c1ccc2ccc(OC)c(C#N)c2n1</smiles><smiles>COC(=O)CCCCC(=O)N(C)CC[C@H](OC(=O)N(C)CCN(C)C(=O)CCl)c1ccc2ccc(OC)c(C#N)c2n1</smiles>

14<smiles>CN(CCN(C)C(=O)CCCCC(=O)ON1C(=O)CCC1=O)C(=O)CCl</smiles>

${ }^{a}$ Reagents and conditions: (a) $\mathrm{MEMCl}, \mathrm{iPr}_{2} \mathrm{NEt}, \mathrm{CH}_{2} \mathrm{Cl}_{2}, 3 \mathrm{~h}$; (b) $\mathrm{SeO}_{2}$, $t$-Bu-OOH, 1,4-dioxane, $45{ }^{\circ} \mathrm{C}, 3 \mathrm{~h}$; (c) allyl bromide, indium, sat. $\mathrm{NH}_{4} \mathrm{Cl}(\mathrm{aq})$, $\mathrm{THF}$, sonication, $55{ }^{\circ} \mathrm{C}, 90 \mathrm{~min}$; (d) $\mathrm{K}_{2} \mathrm{OsO}_{4}$, 2,6lutidine, $\mathrm{NaIO}_{4}, 1: 1 \mathrm{THF} / \mathrm{H}_{2} \mathrm{O}, 12 \mathrm{~h}$; (e) methylamine $(2.0 \mathrm{M}$ in $\mathrm{MeOH}), \mathrm{AcOH}, \mathrm{NaBH}(\mathrm{OAc})_{3}, \mathrm{THF}, 12 \mathrm{~h}$; (f) methyl adipoyl chloride, $\mathrm{CH}_{2} \mathrm{Cl}_{2}$, DIEA, $0{ }^{\circ} \mathrm{C}$ to $\mathrm{rt}, 6 \mathrm{~h}$; (g) carbonyl diimidazole, $\mathrm{CH}_{2} \mathrm{Cl}_{2}, 10 \mathrm{~min}$; (h) $\mathrm{N}, \mathrm{N}^{\prime}$-dimethylethylenediamine, $\mathrm{CH}_{2} \mathrm{Cl}_{2}, 0{ }^{\circ} \mathrm{C}$, $10 \mathrm{~min}$; (i) chloroacetyl chloride, DIEA, $0{ }^{\circ} \mathrm{C}, 4 \mathrm{~h}$; (j) trifluoroacetic acid/water (1:1), $40^{\circ} \mathrm{C}, 12 \mathrm{~h}$; (k) disuccinimidyl carbonate, pyridine, $\mathrm{CH}_{3} \mathrm{CN}, 12 \mathrm{~h}$.

cMO (4a-1, 4b-1, or $4 \mathbf{b}-2)$ in $~ 50 \%$ yield after purification by size exclusion chromatography (NAP-5 column eluting with a water mobile phase).

Photochemical Activation of gad1b MO. Photolysis of the ccMOs at 365 or $405 \mathrm{~nm}$ cleaved the linker, linearizing the cMO (Scheme 4). Gel shift assays were performed to determine the affinity of the gadlb CyHQ-protected cMO $\mathbf{4 b}-\mathbf{1}$ to its sequence specific target both before and after photolysis (Figure 2). Migration of the DNA and the DNA with the caged MO show bands commensurate with the $25 \mathrm{bp}$ size of the fragment. The photolyzed ccMO and the control DNA bound to the underivatized MO show bands at the $150 \mathrm{bp}$ range according to the ladder, because the oligomers are approximately twice the 
Scheme 3. Preparation of $\operatorname{ccMOs}^{a}$

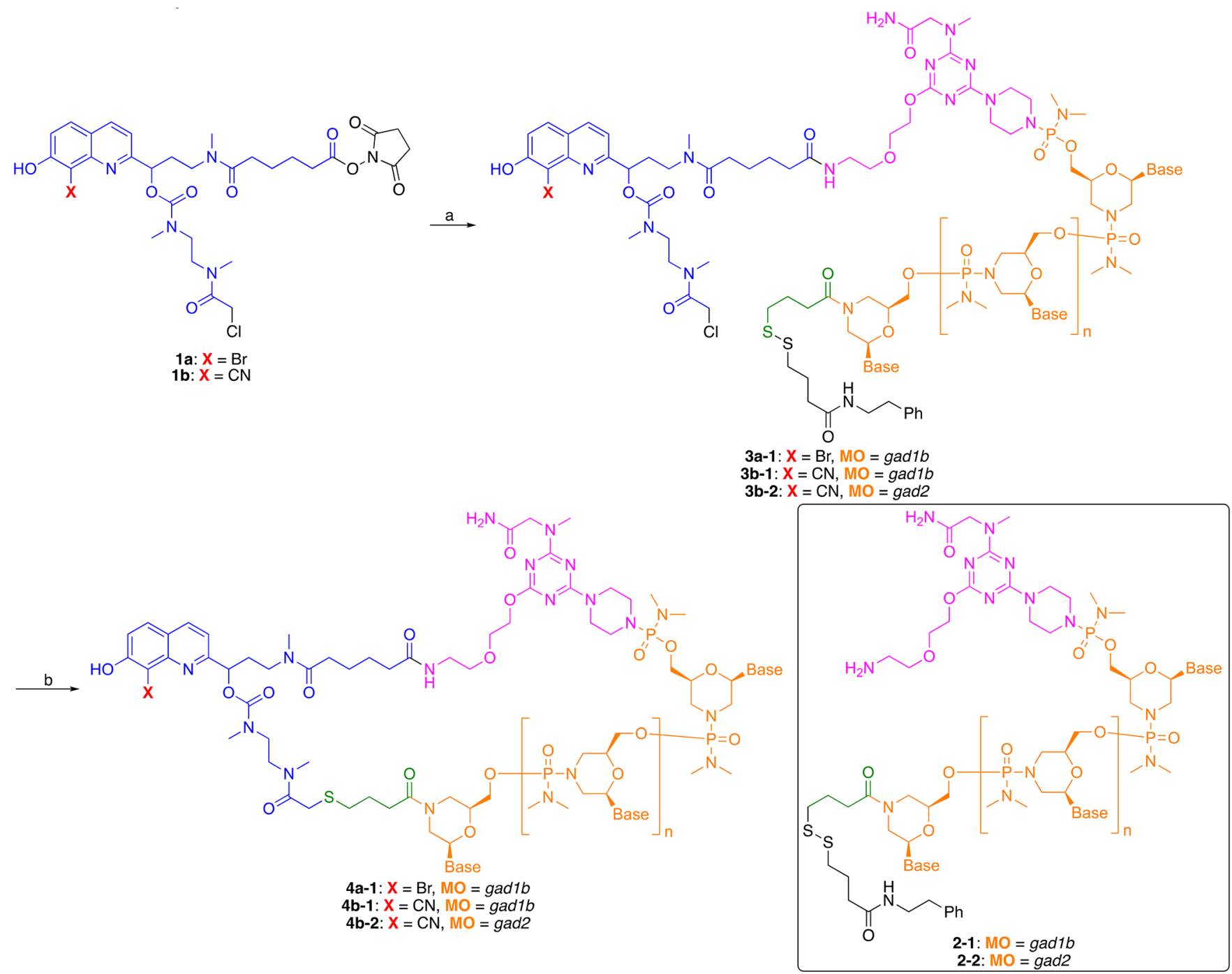

${ }^{a}$ Reagents and conditions: (a) $0.1 \mathrm{M} \mathrm{NaB}_{4} \mathrm{O}_{7}, \mathrm{pH}$ 8.5, DMSO, functionalized $\mathrm{MO}$ with $5^{\prime}$ amino and 3' disulfide (2-1 or 2-2); (b) tris (2carboxyethyl)phosphine (TCEP), resin, $0.1 \mathrm{M}$ Tris-HCl buffer, $\mathrm{pH} 8.4$.

\section{Scheme 4. Photolysis of ccMOs}

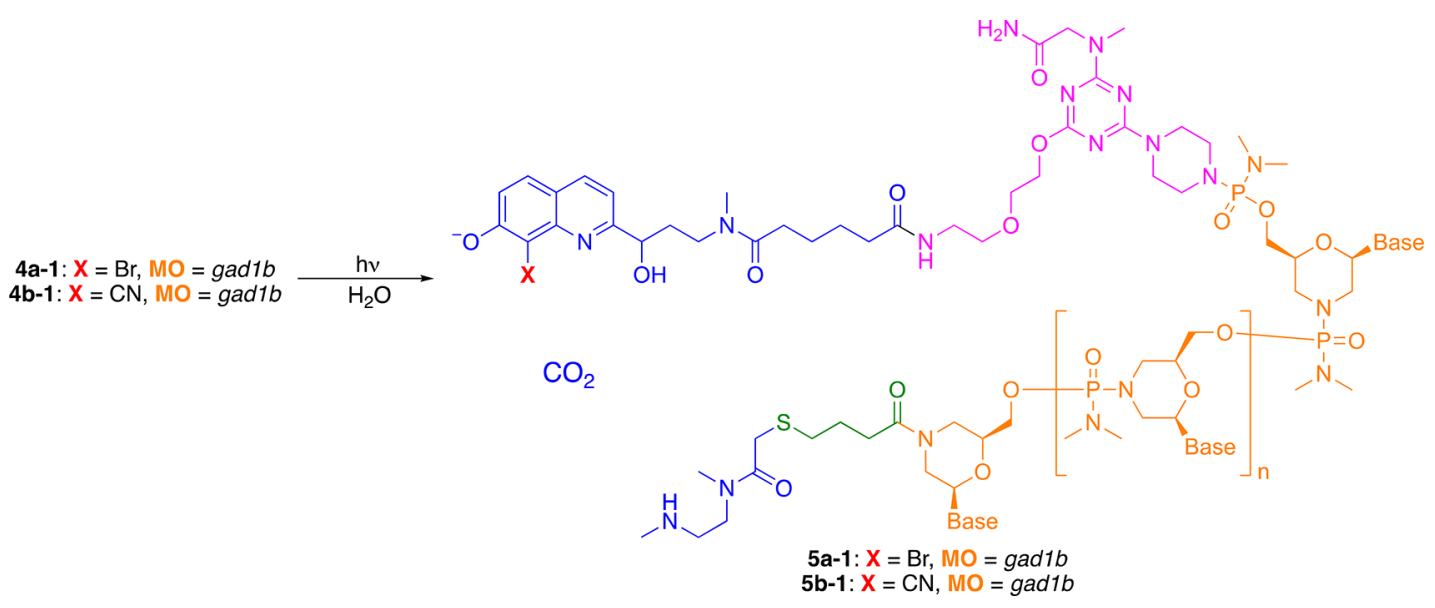

mass and possess half the charge. The result demonstrates that light exposure linearizes the gad $1 b \mathrm{MO}$, thereby facilitating its binding to the complementary DNA, which served as a surrogate for the gad1 mRNA.
An LC-MS/MS experiment was used to quantify the time course of photolysis of CyHQ-GAD1-ccMO (4b-1) at $405 \mathrm{~nm}$ (Figure 3), showing that the gadlb MO is activated rapidly with a quantum efficiency of 0.36 (Table 1 ). Quantitative evaluation 


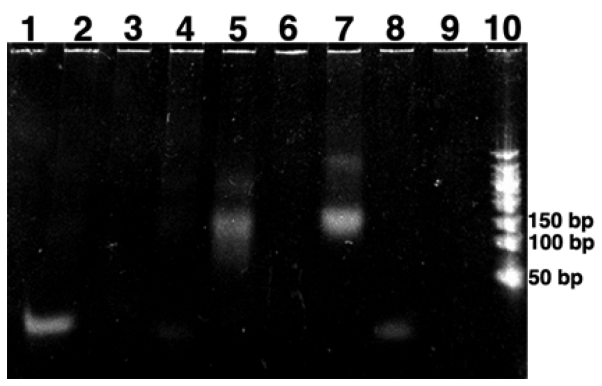

Figure 2. Photoactivation of the gadlb MO from CyHQ-gadlb-ccMO 4b-1. Results of gel shift assay of MO hybridization to its complementary DNA: lane 1, DNA; lanes 2-4, blank; lane 5, DNA and gadlb MO; lane 6, blank; lane 7, DNA, CyHQ-gadlb-ccMO, and light; lane 8, DNA, CyHQ-gad1b-ccMO, no light; lane 9, blank; lane 10, 50 bp DNA ladder.

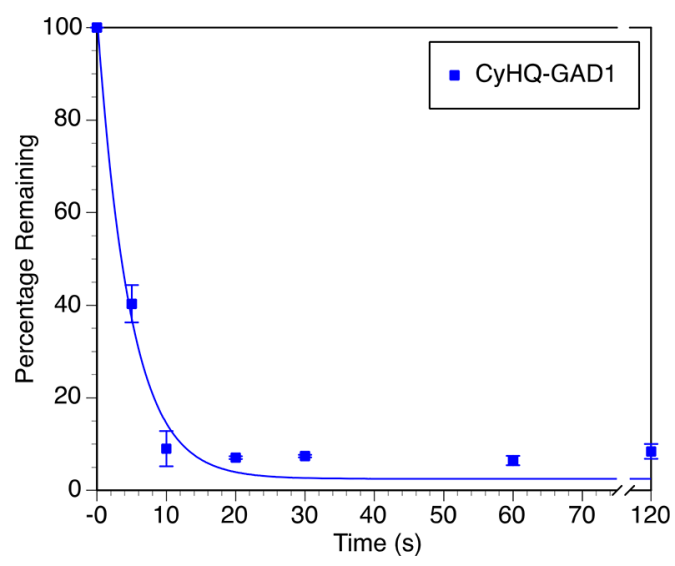

Figure 3. Time course of photolysis at $405 \mathrm{~nm}$ of CyHQ-gad1b-ccMO $(4 \mathbf{b}-\mathbf{1})$ in water $(50 \mu \mathrm{M})$. Each time point is the average of two experiments, and error bars represent the range of the measurement. Lines are least-squares fit of a simple decaying exponential. HPLC trace of CyHQ-gadlb-ccMO (4b-1) before and after photolysis is shown in Figure S3. Deconvoluted MS traces of CyHQ-gadlb-ccMO (4b-1) before and after light exposure are shown in Figures S4 and S5, respectively.

of the photochemistry of BHQ-gad1b-ccMO (4a-1) was not performed because of its low molar absorptivity in the 365-405 $\mathrm{nm}$ range of wavelengths. Experiments in zebrafish (vide infra) show qualitatively photoactivation of $\mathbf{4 a}-\mathbf{1}$. The photochemical properties of CyHQ-gad2-ccMO (4b-2) were not assessed because knocking down gad2 does not cause craniofacial defects, ${ }^{69}$ and the compound was not used in the zebrafish studies. The gad $1 b$ and gad 2 MO sequences differ substantially, demonstrating that a different $\mathrm{MO}$ sequence can be coupled to the photocleaveable linker $\mathbf{1 b}$ and supporting the generality of the strategy for creating photactivatable MOs.

Stability of ccMOs in the Dark. CyHQ-gadlb-ccMO (4b1) is relatively stable in the dark, having a half-life of 11.1 days in Tris buffer ( $\mathrm{pH}$ 7.2) (Figure 4). Under red light and room light,

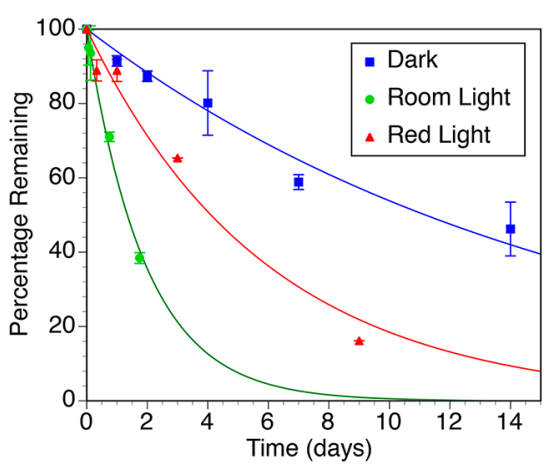

Figure 4. Time course of the degradation of CyHQ-gad1b-ccMO (4b1) in Tris buffer ( $\mathrm{pH} 7.2)$ under three different light conditions (dark, room light, and red light). Each time point is the average of two experiments and error bars represent the range of the measurement. Lines represent the least-squares fit of a single exponential decay.

the half-life decreases to 4.3 and 1.3 days, respectively. Because ccMOs need to work in a living organism, they will be exposed to degradative enzymes, so the stability of the ccMO, MO, and CyHQ-based linker 21 (Scheme S1) toward enzymatic degradation in the dark by representative degradative enzymes (proteinase $\mathrm{K}$, Pronase E, esterase, and benzonase) was also evaluated using an LC-MS/MS assay (Figures S6-S8). CyHQ$\operatorname{gad} 2$-ccMO (4b-2) was used instead of the $g a d 1 b$ version $\mathbf{4 b - 1}$, to conserve precious gad $1 b \mathrm{MO}$ for biological studies. None of the enzymes tested caused degradation of CyHQ-gad2-ccMO (4b-2) more rapidly than that caused by the reaction buffers. Borate buffer ( $\mathrm{pH} \mathrm{8.0)}$ was the most detrimental to $\mathbf{4 b}-\mathbf{2}$. The ccMO was generally more stable than the gad2 MO (2-2) and the pegylated linker 21 . Given the similarity of the structures of 4b-2 and 4b-1, it is reasonable to assume similar stabilities.

CyHQ-gad1b-ccMO Enables Bypass of Craniofacial Defects. Zebrafish embryos injected at the 1-4 cell stage with gad $1 b$ MOs exhibited morphological defects in head development and outgrowth that were visible at 1 day post fertilization (dpf) (Figure 5; Figure S9). Changes visible by light microscopy in live animals included altered distribution of the presumptive head mesenchyme and altered gross structure of the midbrainhindbrain region. By 3 days of development, the gad1b morphant embryos exhibited grossly normal brain structures, but exhibited aberrant jaw morphologies (Figure 6). Assessment of the cartilaginous head skeleton by Alcian blue staining in flat mount preparations at $7 \mathrm{dpf}$ revealed defects in both the neurocranium and the pharyngeal skeleton in $g a d 1 b$ morphant larvae (Figure 7; Figures S10, S11, and S21). The neurocranium includes the ethmoid plate, trabeculae and parachordal cartilages, and the pharyngeal skeleton includes cartilages of the segmented jaw, opercular, and gill-bearing skeleton. ${ }^{23,24}$ Analysis of the neurocranium in gad $1 b$ morphants revealed midline defects of the ethmoid plate and shortened trabeculae (Figure S10). Analysis of the pharyngeal skeleton in $\operatorname{gad} 1 \mathrm{~b}$ morphants revealed midline defects in Meckel's cartilage and the

Table 1. Photophysical and Photochemical Data for ccMOs

\begin{tabular}{cccccc} 
& $\lambda_{\max }(\mathrm{nm})$ & $\varepsilon\left(\mathrm{M}^{-1} \mathrm{~cm}^{-1}\right)$ & $\varepsilon_{405}\left(\mathrm{M}^{-1} \mathrm{~cm}^{-1}\right)$ & $\left.t_{90 \%} \mathrm{~s}\right)$ & $I\left(\text { einstein } \mathrm{cm}^{-2} \mathrm{~s}^{-1}\right)^{a}$ \\
\hline 4a-1 & 265 & 26420 & 460 & & $\mathrm{Q}_{\mathrm{u}}{ }^{a}$ \\
4b-1 & 365 & 26580 & 3160 & 12.3 & $7.1 \times 10^{-8}$ \\
4b-2 & 359 & 26550 & 2650 & & 1214
\end{tabular}

${ }^{a}$ Determined by potassium ferrioxalate actinometry. ${ }^{b}$ Measured at $405 \mathrm{~nm}$. 

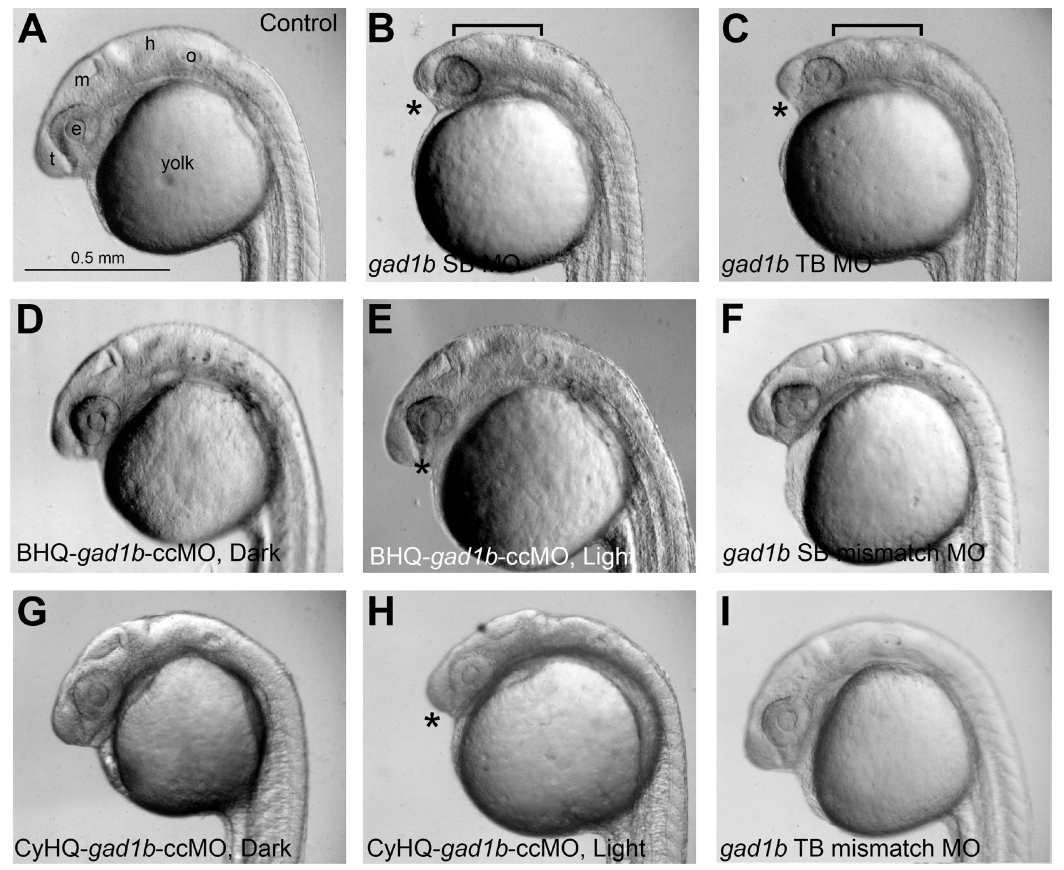

Figure 5. Knockdown of Gadl causes defects in head development and outgrowth visible at $1 \mathrm{dpf}(\mathrm{A})$ wild-type; (B) gadlb splice blocking MO; (C) gad1b translation blocking MO; (D,E) BHQ-gad1b-ccMO; (F) gadlb mismatch control for splice blocking MO; (G,H) CyHQ-gad1b-ccMO; (I) gad $1 b$ mismatch control for translation blocking MO. (D,G) BHQ- and CyHQ-gadlb-ccMO injected embryos raised in the dark exhibit morphological development comparable to wild-type embryos. (E, H) BHQ- and CyHQ-gadlb-ccMO injected embryos raised in the light exhibit morphological development comparable to embryos injected with gadlb splice blocking or translation blocking MOs (B-C). Asterisk denotes regions exhibiting altered distribution of the presumptive head mesenchyme; bracket denotes altered gross structure of the midbrain-hindbrain region. Normal development is observed in embryos injected with 5 base mismatch controls for the gadlb splice blocking MO (F) or translation blocking MO (I). Scale bar in (A) applies to all panels. t, telencephalon; e, eye; m, midbrain; h, hindbrain; o, otocyst.

basihyal cartilage; these structures also exhibited altered cellular packing (Figure 7D,H; Figures S10-S12, S21).

The observed morphological defects were specific to gad $1 b$ MOs, and were observed using translation-blocking (Figures 57, S9-12, S21), splice-inhibiting (Figures 5 and S21), and photocaged $g a d 1 b$ MOs (Figures 5-7) that had been activated immediately after microinjection. Normal development was observed in embryos in which gad $1 b$ translation-blocking MOs were coinjected with synthetic gad $1 b$ mRNA immune to the MO (Figures S9-S11, S27) or injected with gad1b mismatch MOs (Figures 5 and S21). Embryos injected with BHQ-gad1b-ccMO (4a-1) or CyHQ-gad1b-ccMO (4b-1) under red-light conditions and grown in the dark exhibited grossly normal development (Figures 5 and 6) and exhibited normal expression of neural crest markers in premigratory and early migrating neural crest cells (Figure S24). Similarly, embryos injected with gad2 translation-blocking or splice-inhibiting MOs exhibited normal craniofacial development (Figure S9 and S12); however, gad2 morphants exhibit altered neurological activity (Figure S26). Western blot analyses revealed that, in the absence of synthetic mRNA, the MOs against gad $1 b$ and gad 2 were effective in reducing below the limit of detection Gad proteins for the first 3-5 days of development (Figures S13-S20). These data suggest that the gadlb MO perturbs normal craniofacial development. Consistent with this, gadlb morphants exhibited altered expression of early neural crest markers in the head region of embryos just prior to the time of neural crest migration and in early migrating neural crest cells (Figure S22 and S24), and an altered distribution of presumptive migrating chondrogenic neural crest cells in embryos at $1 \mathrm{dpf}$ (Figure S23). The gad $1 b$ morphants at $1 \mathrm{dpf}$ also exhibited an increase in the number of apoptotic cells in the head and pharyngeal arch regions as visualized by acridine orange staining in live embryos (Figure S23).

The craniofacial phenotype in gad $1 b$ morphants is surprising because genetic knockouts of gadlb do not cause craniofacial defects (VanLeuven, A. J.; Ball, R. E.; Carpenter, J. M.; Filipov, N. M.; Lauderdale, J. D., submitted). Given our careful application of controls and rescue experiments following established guidelines to help distinguish specific phenotypes from off-target effects associated with $\mathrm{MOs},{ }^{70}$ we conclude that the gad $1 b$ MO-induced craniofacial phenotype is due to perturbation of GABAergic signaling and represents a more severe phenotype than in gadlb null mutants, as has been observed with other MO-induced phenotypes compared to the corresponding mutants. ${ }^{71}$ Consistent with this idea, treatment of early stage embryos with $\mathrm{GABA}_{\mathrm{A}}$ receptor antagonists alters expression of early neural crest markers in the head region of embryos in a manner similar to that observed in gadlb morphants. One explanation is that the gadlb MO is affecting expression of both gadla and gad1b. Because they have similar mRNA sequences at the translation start site, ${ }^{62}$ the gadlb MO may knockdown expression of both gadla and gadlb. If this is the case, we hypothesize that zebrafish embryos null for gadla and gad $1 b$ will exhibit the craniofacially defective phenotype. Conversely, the gad1b translation blocking MO is an exact match for the sequence around the gadlb translation initiation ATG (Table 2). When compared to gadla, the MO matches 19/ 25 nucleotides, which would be expected to significantly reduce the binding affinity with gadla. Many studies make use of a fivebase mismatch control MO. A recent study investigating offtarget effects of MOs found that 11 consecutive bases 

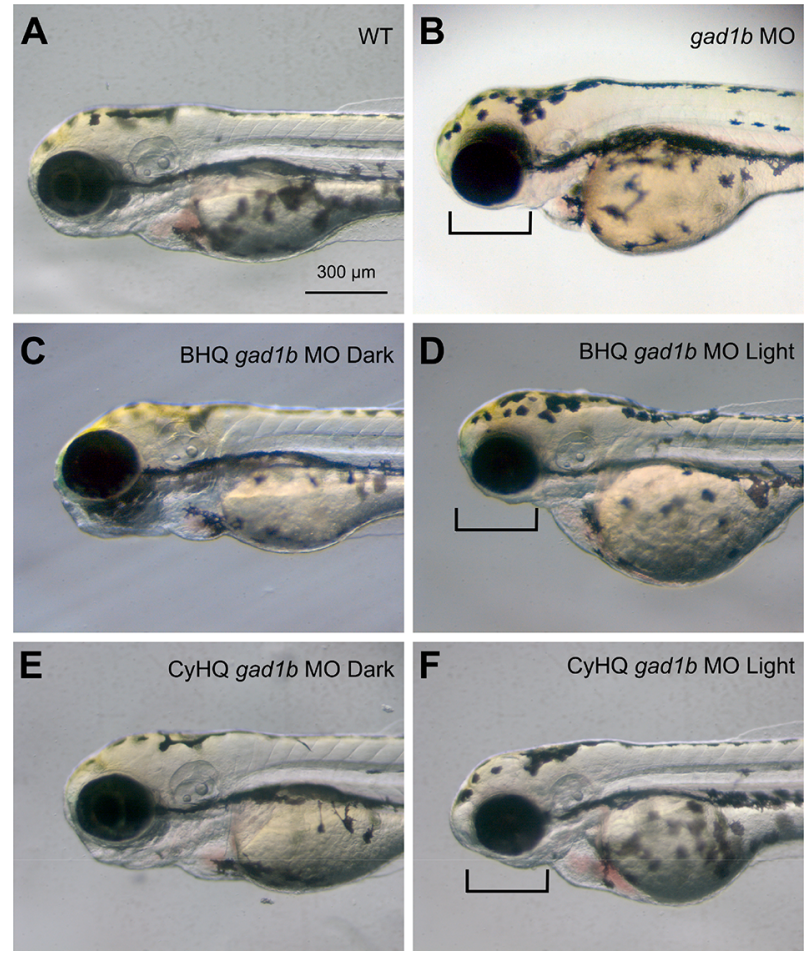

Figure 6. Knockdown of Gad1 causes jaw defects visible at 3 dpf (A) wild-type; (B) gad1b morphant; (C,D) BHQ-gadlb-ccMO; (E,F) CyHQ-gadlb-ccMO. (C,E) BHQ- and CyHQ-gadlb-ccMO injected embryos raised in the dark exhibit morphological development comparable to wild-type embryos. (B, D, F). BHQ- and CyHQgad $1 b$-ccMO injected embryos raised in the light exhibit abnormal development of the presumptive lower jaw (region denoted by bracket) comparable to embryos injected with gadlb MOs; region includes Meckel's cartilage. Scale bar in (A) applies to all panels.

complementary to a target sequence were sufficient for binding and subsequent blocking of splice sites. ${ }^{72}$ The gad $1 b$ translation blocking $\mathrm{MO}$ used in our study has only 8 consecutive bases complementary to $\operatorname{gad} 1 a$, so it seems unlikely that the $\operatorname{gad} 1 b$ translation blocking MO used here would also block translation of gadla. Nevetheless, this cannot be directly tested at this time, because an antibody specific to Gadla has yet to be identified.
Another explanation for the craniofacial phenotype is that the gad1b MO alters isoform expression in a developmentally inappropriate way, and it is this change that leads to altered cartilage development. We detected different isoforms of Gad1 protein in the developing zebrafish, and the pattern of isoform expression changed as a function of development (Figure S13). Interestingly, gad $1 b$ morphants exhibited a shift in gad 1 isoform expression during the period when the MO no longer fully suppressed translation (Figure S16). Although unexpected, this latter mechanism may provide novel insight into gad gene function in non-neural tissues.

To test if we could use photocaged ccMOs to knockdown gad $1 b$ activity while bypassing craniofacial deformities, photoactivation was carried out at 1 day of development. This time point was chosen for two reasons. First, we hypothesized based on the head morphology of gadl 1 morphants at $1 \mathrm{dpf}$ that the defects in the cartilages of the head skeleton were due to perturbation of the cranial neural crest (CNC) cells either before or at the time that these cells were migrating to populate the pharyngeal arches. Beginning at approximately $15 \mathrm{hpf}, \mathrm{CNC}$ cells delaminate from the ectoderm overlying the dorsal neural tube in a wave originating at the midbrain and progress along in caudal direction and migrate as separate streams into the pharyngeal arches. ${ }^{39,40}$ The bulk of this migration occurs between 18 and $24 \mathrm{hpf}$. Neurocranial precursors originate in the midbrain region and migrate between the eyes to form the palatal shelves, and the pharyngeal arches are populated by CNCs that emigrate from the hindbrain. ${ }^{66}$ Second, we wanted to knockdown gad $1 b$ activity in neurons in the developing brain and spinal cord. By $1 \mathrm{dpf}, \operatorname{gad} 1 \mathrm{~b}$ expressing neurons are detectable at all axial levels of the CNS. ${ }^{25,65-67}$

The hypothesis that gadl is expressed in cranial neural crest cells in zebrafish. Mice homozygous for mutations in GAD1, but not $G A D 2$, or in the GABRB3 subunit develop a cleft secondary palate. ${ }^{35-38}$ Administration of GABA to $\mathrm{GAD}_{67}$-deficient mouse fetuses resulted in restoration of the first steps of palate formation. ${ }^{73}$ In humans, mutations in GABRB3 and in the GAD1 comes from human and mouse datatranscript unit have been linked with nonsyndromic cleft lip with or without cleft palate. ${ }^{39,40}$ GABA produced by nonneuronal cells in the palatal epithelium mediates cell proliferation during palatal shelf elevation and subsequently cell migration and/or differentiation during palatal shelf fusion. ${ }^{74}$ During palatogenesis in mice, GAD
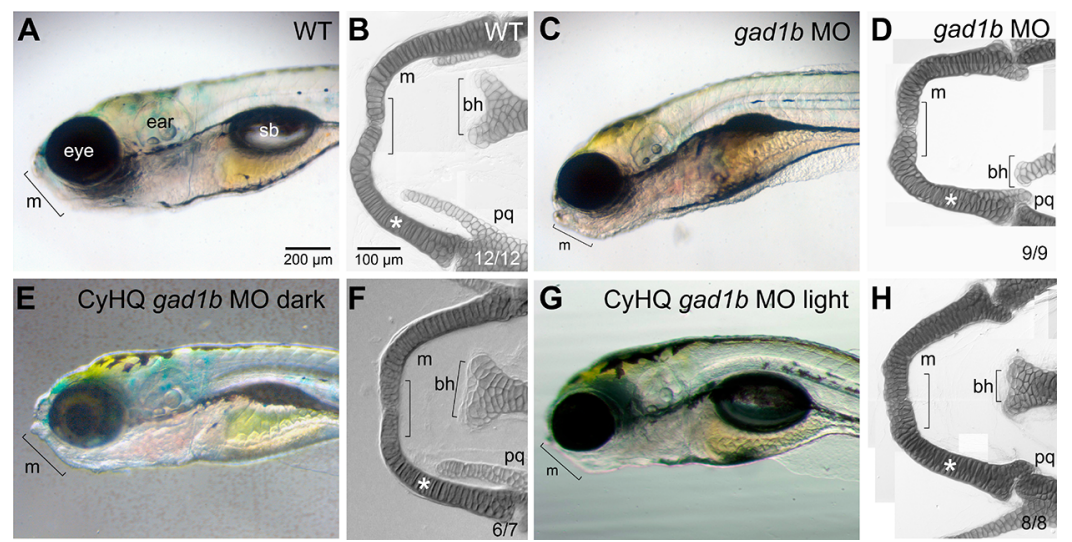

Figure 7. Morphological development of craniofacial features in the developing zebrafish probed by CyHQ-gad1b-ccMO. (A,B) Control fish. (B) Alcian blue stained, flat mount preparation showing normal development of Meckel's (m), basihyal (bh), and palatoquadrate (pq) cartilages. (C,D) The gad $1 b$ morphant fish exhibit reduced Meckel's and basihyal cartilages (denoted with brackets) with midlines defects. Note irregular organization of the cells in the Meckel's cartilage of gadlb morphant fish (asterisk in D and H) compared to controls or ccMO injected fish photoactivated at 1 dpf. 
Table 2. Start Sequence Comparison between gad1a, gad1b, and the gad1b $\mathrm{MO}^{a}$
gad $1 b$
5'-GGACTGATGGCGTCTTCTGCACCTT-3'
$\operatorname{gad} 1 b \mathrm{MO}$
3'-CCTGACTACCGCAGAAGACGTGGAA-5'
gad1a
5'-GaggTGATGGCGgCgTCTGCACCcT-3'
$(25 / 25$ match $)$
(19/25 match)

${ }^{a}$ Mismatched nucleotides in gadla compared to the gad1b MO are denoted in lower case. The start codons for gad1b and $g a d 1 a$ are denoted in bold.

and GABA are expressed in the palatal epithelium of the vertical shelves, in the medial edge epithelium of the horizontally oriented palatal shelves, and in the epithelial seam during fusion. ${ }^{74-76}$ Ubiquitous expression of the $\mathrm{GABA}_{\mathrm{A}} \beta 3$ subunit gene rescued the cleft palate in GABRB3 mutant mice, ${ }^{77}$ neuronal-specific transgene expression did not. ${ }^{74}$ In mice, too much GABA signaling ${ }^{78-80}$ or too little ${ }^{73}$ disrupts palate formation, and a link between benzodiazepine (a potentiator of GABA signaling) use during pregnancy and craniofacial defects has been reported in humans, ${ }^{81-83}$ but is controversial. ${ }^{84}$ These data suggest the process during palatogenesis requires a specific range of GABA signaling during a critical period for normal development; however, the underlying cellular and molecular mechanism are not known. Although secondary palate development does not appear to occur in fish, ${ }^{85,86}$ several lines of evidence are consistent with the idea that GABAergic signaling (and Gad1) is playing a role in the cranial neural crest. In addition to the knock-down data presented (vide supra), treatment of embryos with pentylenetetrazole (PTZ), a GABA antagonist, ${ }^{87}$ phenocopies the increase in cells expressing neural crest markers in the brain comparable to that observed in the morphants (Figure S25). The gad1b gene is expressed in the early embryo as detected by RT-PCR (VanLeuven, A. J.; Ball, R. E.; Gunderson, C. E.; Lauderdale, J. D., submitted).

Zebrafish embryos were injected at the $1-4$ cell stage with CyHQ-gad1b-ccMO (4b-1) under red-light conditions and raised in the dark for the first day of development. Half the injected embryos were then photoactivated and returned to the dark. All embryos were assessed for craniofacial development at 1, 3, and $7 \mathrm{dpf}$ (Figure 7) and for behavioral and electrophysiological correlates of seizure activity at $3 \mathrm{dpf}$ (Figure 8 ). Zebrafish harboring the gad $1 b \mathrm{cMO}$ activated at $1 \mathrm{dpf}$ exhibited normal or near-normal development of the cartilaginous head

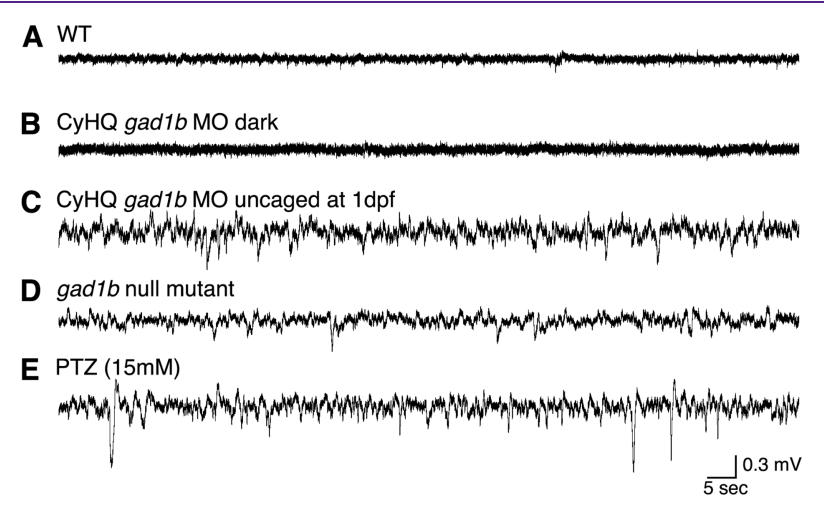

Figure 8. Zebrafish gad1b morphants demonstrate abnormal electrophysiological brain activity. Baseline electrophysiological field recordings from the brain were made at $3 \mathrm{dpf}$ on (A) wild-type zebrafish, (B) fish grown in the dark from CyHQ-GAD1-ccMO (4b-1) injected embryos, (C) fish grown from CyHQ-gadlb-ccMO (4b-1) injected embryos and exposed to light at $1 \mathrm{dpf}$, (D) fish grown from gad1b null mutant embryos $\left(\mathrm{gad}_{1 \mathrm{~b}^{-/}}\right)$, and (E) wild-type fish exposed to $15 \mathrm{mM}$ pentylenetetrazole (PTZ). skeleton (Figure 7), behavioral correlates of seizure (data not shown), and increased and abnormal electrophysiological brain activity compared to wild type animals (Figure 8), consistent with a reduction in GAD function. The electrophysiological traces of the cMO morphants were comparable to those obtained from larvae null for $\mathrm{gad} 1 \mathrm{~b}$ and wild-type fish exposed to PTZ, which causes seizures in zebrafish. ${ }^{88,89}$ PTZ acts by blocking the GABAergic systems, in particular inhibition of $\mathrm{GABA}_{\mathrm{A}}$ receptor-mediated inhibitory postsynaptic potentials. ${ }^{87}$ It has been widely used as a kindling model of epilepsy in rodents $^{90}$ that has recently been extended to frogs and fish. ${ }^{88,91}$ The differences in the voltage amplitude between the recording from the $\mathrm{gad}_{1} \mathrm{~b}^{-/-}$fish (Figure 8D) and the CyHQ-GAD1$\mathrm{ccMO}+$ light fish (Figure $8 \mathrm{C}$ ) might reflect the more severe effect of the MO.

\section{CONCLUSIONS}

Using a photocleavable linker, we prepared BHQ- and CyHQbased ccMOs against gad $1 b$ and gad2. The most efficiently photolyzed compound, CyHQ-gad1b-ccMO (4b-1), had a quantum efficiency of 0.36 and was completely linearized after a brief exposure to $405 \mathrm{~nm}$ light, thereby activating it toward hybridization with its complementary gad $1 b$ mRNA partner. The ccMOs were sufficiently stable in the dark to enable studies in zebrafish that last several days. Importantly, they showed remarkable resistance to representative degradative enzymes proteinase $\mathrm{K}$, Pronase E, esterase, and benzonase. The high $\mathrm{pH}$ buffers used in each of the assays were the sole cause of ccMO degradation; the enzymes had no degradative effects on the ccMOs. Zebrafish embryos injected with BHQ-gadlb-ccMO (4a-1) or CyHQ-gad1b-ccMO (4b-1) and grown in the dark developed normally, effectively bypassing the embryonically lethal effect of knocking down gad 1 expression with a gad $1 b \mathrm{MO}$, and enabling the observation of the abnormal neurological effects of knocking down gad $1 b$ expression in older animals. The photocleavable linker can be cyclized with any MO, so this represents a general strategy for studying the role of embryonically lethal genes at later stages of development in zebrafish.

\section{METHODS}

Genetic Nomenclature. Standard gene nomenclature is used. For zebrafish, gene symbols are lowercase and italicized and protein symbols are capitalized. For other vertebrates, human conventions are used where gene symbols are in all capitals and italicized and protein symbols are in all capitals. With respect to the full name of the ccMOs, the gene symbol is formatted to be consistent with that of the linker

Synthesis. See the Supporting Information for detailed experimental procedures to prepare BHQ linker 1a, CyHQ linker $\mathbf{1 b}$, and CyHQ-linker-PEG 21.

BHQ-gad1b-MO (3a-1), CyHQ-gad1b-MO (3b-1), and CyHQgad2-MO (3b-2). A 25-base gad1 or gad2 MO oligomer with 5'-amine and $3^{\prime}$-disulfide functionalization (2-1, 5'-AAGGTGCAGAAGACGCCATCAGTCC-3', or 2-2, 5'-GAAACCAAAACCCGTGTGATGCCAT-3 $^{\prime}$; 50 or $100 \mathrm{nmol}$; Gene-Tools) was dissolved in $0.1 \mathrm{M}$ $\mathrm{Na}_{2} \mathrm{~B}_{4} \mathrm{O}_{7}, \mathrm{pH} 8.5(100 \mu \mathrm{L})$. Photocleavable linker $\mathbf{1 a}$ or $\mathbf{1 b}(1.0 \mu \mathrm{mol}$, 67 equiv) in DMSO $(15.0 \mu \mathrm{L})$ was added, and the reaction was shaken in the dark until LC-MS indicated that it was complete. The resulting 
mixture was purified on a NAP-5 gel-filtration column and lyophilized; the resulting white solid was dissolved in water $(200 \mu \mathrm{L})$. Acetic acid $(2.00 \mu \mathrm{L})$ was added to the solution, which was then washed successively with chloroform $(3 \times 200 \mu \mathrm{L})$ and EtOAc $(2 \times 200 \mu \mathrm{L})$, and then neutralized with $10 \%$ aq. $\mathrm{NH}_{4} \mathrm{OH}$. The solution was lyophilized to dryness, affording the conjugated product $3 \mathbf{a}-\mathbf{1}, \mathbf{3 b}-\mathbf{1}$, or $\mathbf{3 b}-\mathbf{2}$ as a white solid, which was taken directly to the next step without further purification. BHQ-gad1b-MO (3a-1): MS-ESI-LC-MSQ-TOF $(m / z)[\mathrm{M}]^{+}$calcd for $\mathrm{C}_{349} \mathrm{~N}_{165} \mathrm{O}_{106} \mathrm{H}_{534} \mathrm{P}_{25} \mathrm{ClBrS}_{2} 9688$, found 9688. CyHQ-gad 1b-MO (3b-1): MS-ESI-LC-MS-Q-TOF $(\mathrm{m} / z)[\mathrm{M}]^{+}$ calcd for $\mathrm{C}_{342} \mathrm{~N}_{166} \mathrm{O}_{106} \mathrm{H}_{524} \mathrm{P}_{25} \mathrm{ClS}_{2} 9531$, found 9531. CyHQ-gad2-MO (3b-2): MS-ESI-LC-MS-Q-TOF $(\mathrm{m} / z)[\mathrm{M}]^{+}$calcd for $\mathrm{C}_{342} \mathrm{~N}_{163} \mathrm{O}_{106} \mathrm{H}_{525} \mathrm{P}_{25} \mathrm{ClS}_{2} 9490$, found 9490.

BHQ-gad1b-ccMO (4a-1), CyHQ-gad1b-ccMO (4b-1), and CyHQgad2-cCMO (4b-2). Gel-immobilized TCEP $(100 \mu \mathrm{L})$ (Pierce Biotechnology) was washed with $0.1 \mathrm{M}$ Tris- $\mathrm{HCl}$ buffer, $\mathrm{pH} 8.4(3 \times$ $100 \mu \mathrm{L})$ in a centrifuge filter tube. BHQ-GAD1MO (3a-1) or CyHQGAD1MO (3b-1) was dissolved in $0.1 \mathrm{M}$ Tris- $\mathrm{HCl}$ buffer, $\mathrm{pH} 8.4$ (100 $\mu \mathrm{L}$ ) and added to the washed gel; the reaction was shaken for $10 \mathrm{~h}$ in the dark. The supernatant was collected by centrifuge at $1000 \mathrm{rpm}$ for $30 \mathrm{~s}$. The gel slurry was washed with $0.1 \mathrm{M}$ Tris-HCl buffer, $\mathrm{pH} 8.4(3 \times 100$ $\mu \mathrm{L}$ ), and the eluted fractions were combined with the supernatant. This mixture was purified on a NAP-5 gel-filtration column and lyophilized to afford $4 \mathrm{a}-\mathbf{1}$ ( $8.2 \mathrm{nmol}, 17 \%$ over 2 steps), $\mathbf{4 b - 1}$ ( $35.1 \mathrm{nmol}, 35 \%$ over 2 steps), or $4 \mathbf{b}-2$ ( $29.0 \mathrm{nmol}, 29 \%$ over 2 steps). BHQ-gadlb-ccMO (4a-1): MS-ESI-LC-MS-Q-TOF $(m / z)[\mathrm{M}]^{+}$calcd for $\mathrm{C}_{337} \mathrm{~N}_{161} \mathrm{O}_{105} \mathrm{H}_{518} \mathrm{P}_{25} \mathrm{BrS}$ 9431,found 9433. CyHQ-gad1b-ccMO (4b1): MS-ESI-LC-MS-Q-TOF $(m / z) \quad[\mathrm{M}]^{+}$calcd for $\mathrm{C}_{338} \mathrm{~N}_{165} \mathrm{O}_{105} \mathrm{H}_{516} \mathrm{P}_{25} \mathrm{~S}$ 9377, found 9376. CyHQ-gad2-ccMO (4b-2): MS-ESI-LC-MS-Q-TOF $(\mathrm{m} / z)[\mathrm{M}]^{+}$calcd for $\mathrm{C}_{338} \mathrm{~N}_{162} \mathrm{O}_{105} \mathrm{H}_{517} \mathrm{P}_{25} \mathrm{~S}$ 9336, found 9336.

Photochemistry. Gel Shift Assay. Solutions $(0.88 \mu \mathrm{M})$ of nonderivatized MO, its antisense DNA ( $5^{\prime}$-TTCCACGTCTTCTGCGGTAGTCAGG-3'), irradiated ccMO (10 min exposure to light from a mercury lamp to achieve complete photolysis), and nonirradiated ccMO were prepared in TBE buffer. Light-sensitive materials were handled in the dark or under red safety lamps. Four samples were prepared as follows: DNA solution $(8 \mu \mathrm{L})$, DNA solution $(8 \mu \mathrm{L})$ and MO $(8 \mu \mathrm{L})$, DNA solution $(8 \mu \mathrm{L})$ and photolyzed $\operatorname{ccMO}(8 \mu \mathrm{L})$, and unphotolyzed ccMO $(8 \mu \mathrm{L})$ and DNA solution $(8 \mu \mathrm{L})$. Hybridization was performed by heating the samples in a water bath $\left(45^{\circ} \mathrm{C}\right)$ for 30 min followed by cooling on ice. Loading buffer $(3 \mu \mathrm{L}, 5 \times)$ was added to each sample, which was subsequently loaded onto $12 \%$ native PAGE gel. The gel was run with a $50 \mathrm{bp}$ ladder (GelPilot, Qiagen) at $40 \mathrm{~V}$ for $3.5 \mathrm{~h}$. Gels were stained with SYBR Gold nucleic acid gel stain (Thermo Fisher Scientific) for $30 \mathrm{~min}$ for visualization.

Quantum Efficiency. Compound $\mathbf{1 b}$ was dissolved in water, and an aqueous solution of gad $1 b$ MO (internal standard) was added to a final concentration of $50 \mu \mathrm{M}$ for both analytes. Aliquots $(50 \mu \mathrm{L})$ of the solution were placed in a microcuvette $(26.10 \mathrm{~F}-\mathrm{Q}-10$, Starna, Atascadero, CA, $10 \times 1 \times 1 \mathrm{~mm}^{3}$ illuminated dimensions) and irradiated for different time intervals $(0,5,10,20,30$, and $60 \mathrm{~s})$ with a LED lamp (Cairn OptoLED Lite) at $405 \mathrm{~nm}$. Each time point was repeated in duplicate. The irradiated solutions were analyzed by LCMS/MS (Agilent UHD Accurate-Mass QTOF LC/MS system 6540, Agilent Technologies, Palo Alto, CA) to quantify the residual concentration of $\mathbf{1 b}$. Chromatographic profiles were obtained using an Agilent PLRP-S C18 column $150 \times 4.6 \mathrm{~mm}$ with $8 \mu \mathrm{m}$ particle size and gradient elution: eluent $\mathrm{A}$ being acetonitrile and eluent $\mathrm{B}$ consisting of water. The analysis started with $2 \%$ of eluent $A$, which was linearly increased up to $100 \%$ in $20 \mathrm{~min}$, then remaining at $100 \%$ until $30 \mathrm{~min}$. The flow rate was $0.5 \mathrm{~mL} \mathrm{~min}{ }^{-1}$, and injection volume was $10 \mu \mathrm{L}$. Quantification of the eluted material was obtained by developing an appropriate MS-MS method using the QTOF detector. Collision induced dissociation was performed with a fixed collision energy set at $40 \mathrm{eV}$ and two transitions were recorded at $\mathrm{m} / z 1563.8$ and 1849.5, operating the MSD in positive ion mode. Quantitative data were obtained by comparison to standard calibration curves using the Agilent MassHunter Workstation Software for Quantitative Analysis. The percentages of compound left in solution were plotted versus time of irradiation and fitted to a single exponential decay curve using the software DeltaGraph (Red Rock Software, Inc.). The quantum efficiency $\left(Q_{\mathrm{u}}\right)$ of the photolysis reaction was determined as previously described, ${ }^{33}$ using the following equation: $Q_{\mathrm{u}}=\left(I \sigma t_{90 \%}\right)^{-1,92}$ where $I$ is the intensity of the lamp in einstein $\mathrm{cm}^{-2} \mathrm{~s}^{-1}$ (measured by ferrioxalate actinometry $\left.{ }^{93}\right), \sigma$ is the decadic extinction coefficient $(1000 \varepsilon$, molar extinction coefficient), and $t_{90 \%}$ is the time in seconds required for $90 \%$ of the starting material to be photolyzed.

Stability Studies. Stability in the Dark, Red Light, and Room Light. CyHQ-gad1b-ccMO (4b-1) was dissolved in Tris buffer (150 $\mathrm{mM} \mathrm{KCl}, 10 \mathrm{mM}$ Tris- $\mathrm{HCl}, \mathrm{pH} 7.2$, phenol red $0.01 \%$ ) to a final concentration of $100 \mu \mathrm{M}$. Aliquots of the solution $(50 \mu \mathrm{L})$ were placed in microcentrifuge tubes and exposed to different light conditions (dark, room white light, red light). The tubes were sampled $(6 \mu \mathrm{L})$ after different time intervals and aqueous solutions of the internal standard ( gad1b MO100 $\mu \mathrm{M})$ were added $(6 \mu \mathrm{L})$ to a final concentration of 50 $\mu \mathrm{M}$ for both analytes. Quantitative data were obtained with the same LC-MS/MS method described for the photolysis experiment. The experiment was performed in duplicate. The percentage of CyHQgad1b-ccMO (4b-1) remaining in solution was plotted against time and fitted to a single exponential decay curve with the software DeltaGraph (Red Rock Software Inc.). Three different curves were generated, representing the three conditions evaluated (dark, room white light, red light). Half-life $\left(t_{1 / 2}\right)$ values were obtained from the corresponding curve equation.

Stability Toward Enzymatic Degradation. CyHQ-gadlb-ccMO $(\mathbf{4 b}-2)(3 \mathrm{nmol})$ was dissolved in the appropriate buffer (Table 3) and a

Table 3. Experimental Conditions for the Enzymatic Stability Experiment

\begin{tabular}{|c|c|c|c|}
\hline enzyme & buffer & enzyme concen & temperature \\
\hline proteinase $\mathrm{K}$ & $\begin{array}{l}\text { Tris } 50 \mathrm{mM}, \mathrm{CaCl}_{2} 5 \\
\text { mM, pH } 7.8\end{array}$ & $\begin{array}{l}0.4 \mathrm{mg} / \mathrm{mL} \\
\quad(0.6 \mathrm{U} / \text { reaction })\end{array}$ & $37^{\circ} \mathrm{C}$ \\
\hline pronase $\mathrm{E}$ & $\begin{array}{l}\text { Tris } 50 \mathrm{mM}, \mathrm{CaCl}_{2} 5 \\
\mathrm{mM}, \mathrm{pH} 7.8\end{array}$ & $\begin{array}{l}1.4 \mathrm{mg} / \mathrm{mL} \\
(0.2 \mathrm{U} / \text { reaction })\end{array}$ & $37^{\circ} \mathrm{C}$ \\
\hline esterase & borate $10 \mathrm{mM}, \mathrm{pH} 8.0$ & $\begin{array}{l}3.3 \mathrm{mg} / \mathrm{mL} \\
(2.5 \mathrm{U} / \text { reaction })\end{array}$ & $25^{\circ} \mathrm{C}$ \\
\hline benzonase & $\begin{array}{l}\text { Tris } 20 \mathrm{mM}, \mathrm{MgCl}_{2} 2 \\
\text { mM, NaCl } 20 \mathrm{mM} \text {, } \\
\text { pH } 8.0\end{array}$ & $\begin{array}{l}0.5 \mu \mathrm{L} \\
\quad(125 \mathrm{U} / \text { reaction })\end{array}$ & $37^{\circ} \mathrm{C}$ \\
\hline
\end{tabular}

fresh solution of enzyme in buffer was added. Aliquots of the resulting solution $(50 \mu \mathrm{L})$ were placed in microcentrifuge tubes and incubated at the appropriate temperature (Table 3) in the dark. A control experiment without enzyme was also performed under the same conditions. The tubes were sampled $(10 \mu \mathrm{L})$ after different time intervals $(0,2$, and 4 days) and combined with aqueous solutions of the internal standard (gad2 MO) $(10 \mu \mathrm{L})$. Quantitative data were obtained with the same LC-MS/MS method described for the photolysis experiments. Each experiment was performed in triplicate. The same experimental conditions were also used to evaluate the enzymatic stability of the two separate portions of CyHQ-gadlb-ccMO (4b-2): the ad-hoc synthesized linker portion (CyHQ-linker-PEG, 21) and the MO alone (gad2 MO, 2-2).

A positive control experiment was run in parallel for each enzyme to ensure that the hydrolase was active under the assay conditions. The control substrate for the proteolytic and esterolytic enzymes was $\mathrm{N}$ acetyl-L-tyrosine ethyl ester (Ac-Tyr-OEt), bearing both the ester and amide functionality. Almost complete hydrolysis (>90\%) of Ac-TyrOEt was observed after 10 min of incubation in all cases (HPLC). An in-house DNA sequence was used as a positive control for the benzonase stability experiment. Degradation of the DNA was monitored by UV-vis spectroscopy $\left(\Delta A_{265}\right)$ with a NanoDrop spectrophotometer. A $50 \%$ increase of absorptivity was found after 1 $\mathrm{h}$ of incubation with benzonase, confirming DNA hydrolysis.

Zebrafish Studies. Zebrafish Maintenance. Adult and larval zebrafish (Danio rerio) were obtained from lines maintained in the University of Georgia Zebrafish Facility following standard procedures. $^{94}$ Embryos and larvae were staged using standard staging 
criteria. ${ }^{94,95}$ Wild-type fish of the WIK strain were originally obtained from the Zebrafish International Research Center (ZIRC). The line of zebrafish mutant for gad $1 b$ was generated by CRISPR-Cas9 mediated genome editing of the gad $1 b$ locus. Additional details will be provided in a separate publication (VanLeuven, A. J.; Ball, R. E.; Carpenter, J. M.; Filipov, N. M.; Lauderdale, J. D., submitted). The gad1 $b^{\text {gav2303/gav2303 }}$ allele used in these studies harbored a $10 \mathrm{bp}$ deletion in exon 4 and was a functional null mutation. All adult fish were maintained in an Aquatic Habitats (Apopka, FL) multirack system. Habitat water consisted of reverse osmosis filtered/sterilized water to which sodium bicarbonate and other salts (Instant Ocean, Aquarium Systems, Inc., Mentor, $\mathrm{OH}$ ) were added to maintain $\mathrm{pH}$ from 7.0 to 7.4 and conductivity between 400 and $430 \mu \mathrm{S}$. All experimental procedures were conducted in accordance with National Institutes of Health guidelines for use of zebrafish in research under protocols approved and overseen by the University of Georgia Institutional Animal Care and Use Committee.

Morpholino Microinjection and mRNA Rescue. MOs were microinjected using pressure into one to four-cell stage embryos following standard protocols ${ }^{70,71,96,97}$ under red-light conditions. Approximately $1 \mathrm{~nL}$ was injected into each embryo at the following concentrations: gad1 MO, $0.3 \mathrm{ng} / \mathrm{nL}$; gad2 MO $1 \mathrm{ng} / \mathrm{nL}$; BHQ- or CyHQ-gadl-ccMO, 0.35-0.45 ng/nL. See Figures S14-S17 for titration data of gad $1 b$ and gad2 MOs. The following 5 base mismatch controls were used: gadlb translation blocking mismatch MO, 5'AAGCTCCAGAACACCCCATCACTCC-3'; gad2 translation blocking mismatch MO 5'-GATAGCAAAAGCCGTCTCATGCCAT-3'. In rescue experiments, a synthetic gad $1 b$ mRNA was coinjected with the gadlb MO. The synthetic gadlb mRNA lacked the gadlb MO target sequence while preserving the amino acid sequence; specifically, the

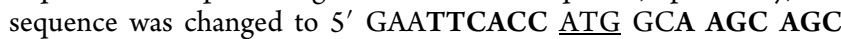
GCT CCA TCT... where the nucleotides in bold were changed from the endogenous sequence and the translation initiation site is underlined. See Figure S22 for titration data of synthetic gad1 mRNA.

Drugs. The pentylenetetrazol (PTZ) used for this study was purchased from Sigma-Aldrich (cat. \#P6500, St. Louis, MO). Stock PTZ solutions of $300 \mathrm{mM}$ were prepared in distilled water following protocols used for administration to mammals ${ }^{98}$ and stored in aliquots at $-20{ }^{\circ} \mathrm{C}$. Compounds dissolved in embryo medium are readily absorbed through the gastrointestinal tract or across the skin of larvae. ${ }^{99}$

Electrophysiology. Electrophysiological recordings were collected from $3 \mathrm{dpf}$ zebrafish following protocols established for $7 \mathrm{dpf}$ larvae. ${ }^{88}$ Briefly, zebrafish larvae were immobilized by exposure to $250 \mu \mathrm{M} \alpha$ bungarotoxin (Life Technologies/ThermoFisher, cat. \#B1601) ${ }^{100}$ in E3 medium $\left(5 \mathrm{mM} \mathrm{NaCl}, 0.17 \mathrm{mM} \mathrm{KCl}, 0.33 \mathrm{mM} \mathrm{CaCl}_{2}, 0.33 \mathrm{mM}\right.$

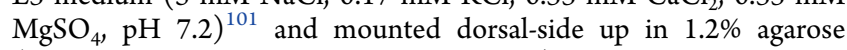
(Thermo Fisher Scientific, Waltham, MA) in E3 medium. After embedding, larvae were placed on the upright stage of a Zeiss Examiner.Z1 microscope (Carl Zeiss Microscopy, LLC One Zeiss Drive Thornwood, NY 10594) and bathed with fresh E3 media. Under direct visual guidance, a glass microelectrode (approximately $1 \mu \mathrm{m}$ tip diameter, 5-10 M $\Omega$ impedance) was placed in the optic tectum. The optic tectum was chosen to facilitate comparison with previously published data obtained from larval zebrafish. ${ }^{88}$ Electrodes were were filled with $2 \mathrm{M} \mathrm{NaCl}$. A chloride-coated silver wire (0.010 in., A-M Systems, Inc. Sequim, WA) reference electrode was placed touching the medulla or spinal cord. Field recordings were collected using an Axoclamp 900a amplifier (Axon Instruments, Union City, CA). The amplified voltage was passed through a Hum Bug Noise Eliminator (AutoMate Scientific, Berkley, CA), band-pass filtered from 1 to 0.1 $\mathrm{kHz}$, and digitized at $10 \mathrm{kHz}$ using a Digidata 1440 interface and stored on a PC using pClamp software (version 10.3, Molecular Devices). Experiments were carried out at $23 \pm 0.5^{\circ} \mathrm{C}$. To chemically induce seizures, larvae immobilized in agar were exposed to E3 medium containing $15 \mathrm{mM} \mathrm{PTZ,} \mathrm{which} \mathrm{is} \mathrm{a} \mathrm{concentration} \mathrm{shown} \mathrm{to} \mathrm{reliably}$ induce clonus-like seizure behavior. ${ }^{88}$

Western Blot Analysis. Western analysis was performed following standard protocols. ${ }^{102,103}$ To determine MO knockdown of gad gene encoded proteins, 30-100 embryos per injection set were collected at 3 $\mathrm{dpf}$, deyolked in ice-cold calcium-free Ringer's solution $(116 \mathrm{mM} \mathrm{NaCl}$, $2.9 \mathrm{mM} \mathrm{KCl}, 5.0 \mathrm{mM}$ HEPES, $\mathrm{pH} 7.2),{ }^{94}$ and homogenized in a solution containing $60100 \mu \mathrm{L}$ RIPA buffer (cat. \#89900, Thermo Fisher Scientific Inc., Waltham, MA) with 1 mM EDTA solution and 1 mM protease inhibitor cocktail (cat. \#P8340, Sigma-Aldrich, St. Louis, MO). Samples were centrifuged for $10 \mathrm{~min}$ at $18000 \mathrm{~g}$ and the supernatant collected and stored at $-80{ }^{\circ} \mathrm{C}$ until further use. Protein concentration was measured by Bradford assay. ${ }^{104}$ Samples containing $10 \mu \mathrm{g}$ of total protein were separated by SDS-PAGE and transferred to $0.45 \mu \mathrm{m}$ nitrocellulose membrane (Bio Rad, Hercules, CA). Blots were probed using a mouse monoclonal to $\mathrm{GAD}_{67}$ (cat. \#sc-58531, Santa Cruz Biotechnology Inc.) at a 1:200 dilution, a rabbit polyclonal to Gad2 (cat. \#55772, AnaSpec, Inc., Freemont, CA) at a 1:1000 dilution and a rabbit polyclonal to GAPDH (ab9484, Abcam, Cambridge, MA) at a 1:10,000 dilution. Bands were visualized by chemiluminescence (Immun-Star WesternC chemiluminescence kit, Bio Rad, Hercules, CA).

Alcian Blue Staining of Cartilages. Cartilage staining was performed using a modified protocol of Kimmel et al. ${ }^{105}$ Briefly, larvae were fixed in 4\% PFA/PBS pH 7.0 at room temperature for $1 \mathrm{~h}$. Larvae were washed three times in $70 \%$ ethanol $(\mathrm{EtOH})$, and $30 \%$ hydrochloric acid $(\mathrm{HCl})$ for $5 \mathrm{~min}$. Larvae were stained overnight in a solution of $0.1 \%$ alcian blue, $70 \% \mathrm{EtOH}$, and $30 \% \mathrm{HCl}$. Samples were then differentiated in $70 \% \mathrm{EtOH}$ and $30 \% \mathrm{HCl}$ until no blue color remained in the solution. For whole mount analysis, depigmented larvae were stepwise rehydrated to water and then cleared in a series of glycerol/1\% $\mathrm{KOH}$. For flat mount analysis, larvae were stepwise rehydrated to water and then rinsed three times in saturated sodium borate solution. Tissues were macerated in 3\% trypsin in equal volumes of water and sodium borate for 15-30 min. Cartilages were dissected out using fine forceps and samples were rinsed in water before flat mounting.

Whole mount alcian stains were mounted laterally and ventrally in 3\% methylcellulose in PBS and imaged on a Leica MZ FLIII fluorescent dissecting microscope connected to a computer running Leica FireCam image capture software (Leica Microsystems, Buffalo Grove, IL). Images were loaded into Adobe PhotoShop (Adobe Systems Inc., San Jose, CA) and cartilage length was measured for the bones that were not obstructed by tissue. Flat mounted cartilages were digitally photographed using a Zeiss Axioscope (Carl Zeiss Microscopy, LLC, One Zeiss Drive, Thornwood, NY 10594). The Cell Counter plugin of Image ${ }^{106}$ was used to analyze and count cells in flat mount cartilages.

\section{ASSOCIATED CONTENT}

\section{S Supporting Information}

The Supporting Information is available free of charge on the ACS Publications website at DOI: 10.1021/acschemneuro.8b00231.

Preparation of $\mathrm{BHQ}$ - and CyHQ-based linkers $\mathbf{1 a}$ and $\mathbf{1 b}$ and CyHQ-linker-PEG (21), ${ }^{1} \mathrm{H}$ NMR and ${ }^{13} \mathrm{C}$ NMR spectra, UV-vis spectra, HPLC chromatograms, MS spectra; MO knockdown; enzymatic stability; Western blot analysis (PDF)

\section{AUTHOR INFORMATION}

\section{Corresponding Authors}

*(T.M.D.) Phone: +971 2628 4762. E-mail: timothy.dore@ nyu.edu.

*(J.D.L.) Phone: +1 706542 7433. E-mail: jdlauder@uga.edu. ORCID ${ }^{\circ}$

Timothy M. Dore: 0000-0002-3876-5012

\section{Author Contributions}

M.J.O., L.L.B., D.D., R.E.B., A.T.P., A.J.V., K.T.H., S.P., and V.H. provided input into experimental design, conducted the experiments, interpreted the results, and assisted with writing the manuscript. M.J.O., L.L.B., and D.D. contributed equally. J.D.L. and T.M.D. conceived the overall idea, designed the 
experiments, interpreted the results, and wrote and edited the manuscript.

\section{Funding}

Supported by Grants R01 NS070159 from the National Institutes of Health to T.M.D. and J.D.L., R01 NS090645 from the National Institutes of Health to J.D.L., CHE-1012412 and CHE-1317760 from the National Science Foundation to T.M.D., and New York University Abu Dhabi.

\section{Notes}

The authors declare no competing financial interest.

\section{ACKNOWLEDGMENTS}

Lindsey McQuade, Ilya Shestopalov, and James K. Chen provided helpful advice. Part of the work was carried out using Core Technology Platform resources at New York University Abu Dhabi and mass spectrometry resources at the Proteomics and Mass Spectrometry Core Facility at the University of Georgia.

\section{ABBREVIATIONS}

GAD1, glutamic acid decarboxylase 1; GAD2, glutamic acid decarboxylase 2

\section{REFERENCES}

(1) Brooks-Kayal, A. R., Raol, Y. H., and Russek, S. J. (2009) Alteration of epileptogenesis genes. Neurotherapeutics 6, 312-318.

(2) Hortopan, G. A., Dinday, M. T., and Baraban, S. C. (2010) Spontaneous seizures and altered gene expression in GABA signaling pathways in a mind bomb mutant zebrafish. J. Neurosci. 30, 1371813728.

(3) Kash, S. F., Johnson, R. S., Tecott, L. H., Noebels, J. L., Mayfield, R. D., Hanahan, D., and Baekkeskov, S. (1997) Epilepsy in mice deficient in the $65-\mathrm{kDa}$ isoform of glutamic acid decarboxylase. Proc. Natl. Acad. Sci. U. S. A. 94, 14060-14065.

(4) Akbarian, S., and Huang, H.-S. (2006) Molecular and cellular mechanisms of altered GAD1/GAD67 expression in schizophrenia and related disorders. Brain Res. Rev. 52, 293-304.

(5) Guidotti, A., Auta, J., Davis, J. M., Gerevini, V. D., Dwivedi, Y., Grayson, D. R., Impagnatiello, F., Pandey, G., Pesold, C., Sharma, R., Uzunov, D., and Costa, E. (2000) Decrease in reelin and glutamic acid decarboxylase67 (GAD67) expression in schizophrenia and bipolar disorder a postmortem brain study. Arch. Gen. Psychiatry 57, 10611069.

(6) Addington, A. M., Gornick, M., Duckworth, J., Sporn, A., Gogtay, N., Bobb, A., Greenstein, D., Lenane, M., Gochman, P., Baker, N., Balkissoon, R., Vakkalanka, R. K., Weinberger, D. R., Rapoport, J. L., and Straub, R. E. (2005) GAD1 (2q31.1), which encodes glutamic acid decarboxylase (GAD67), is associated with childhood-onset schizophrenia and cortical gray matter volume loss. Mol. Psychiatry 10, 581588.

(7) Hossein Fatemi, S., Stary, J. M., Earle, J. A., Araghi-Niknam, M., and Eagan, E. (2005) GABAergic dysfunction in schizophrenia and mood disorders as reflected by decreased levels of glutamic acid decarboxylase 65 and $67 \mathrm{kDa}$ and Reelin proteins in cerebellum. Schizophr. Res. 72, 109-122.

(8) Fatemi, S. H., Halt, A. R., Stary, J. M., Kanodia, R., Schulz, S. C., and Realmuto, G. R. (2002) Glutamic acid decarboxylase 65 and 67 $\mathrm{kDa}$ proteins are reduced in autistic parietal and cerebellar cortices. Biol. Psychiatry 52, 805-810.

(9) Lynex, C. N., Carr, I. M., Leek, J. P., Achuthan, R., Mitchell, S., Maher, E. R., Woods, C. G., Bonthon, D. T., and Markham, A. F. (2004) Homozygosity for a missense mutation in the $67 \mathrm{kDa}$ isoform of glutamate decarboxylase in a family with autosomal recessive spastic cerebral palsy: parallels with Stiff-Person Syndrome and other movement disorders. BMC Neurol. 4, 20.
(10) Levy, L. M., Dalakas, M. C., and Floeter, M. K. (1999) The stiffperson syndrome: an autoimmune disorder affecting neurotransmission of gamma-aminobutyric acid. Ann. Intern. Med. 131, 522-530.

(11) Jessen, K. R., Hills, J. M., and Saffrey, M. J. (1986) Immunohistochemical demonstration of GABAergic neurons in the enteric nervous system. J. Neurosci. 6, 1628-1634.

(12) Bowery, N. G., Doble, A., Hill, D. R., Hudson, A. L., Shaw, J. S., Turnbull, M. J., and Warrington, R. (1981) Bicuculline-insensitive GABA receptors on peripheral autonomic nerve terminals. Eur. J. Pharmacol. 71, 53-70.

(13) Hill, D. R., and Bowery, N. G. (1981) 3H-baclofen and 3HGABA bind to bicuculline-insensitive GABA B sites in rat brain. Nature 290, 149-152.

(14) Krantis, A. (2000) GABA in the mammalian enteric nervous system. Physiology 15, 284-290.

(15) Karlsen, A. E., Hagopian, W. A., Grubin, C. E., Dube, S., Disteche, C. M., Adler, D. A., Barmeier, H., Mathewes, S., Grant, F. J., et al. (1991) et al Cloning and primary structure of a human islet isoform of glutamic acid decarboxylase from chromosome 10. Proc. Natl. Acad. Sci. U. S. A. $88,8337-8341$.

(16) Rorsman, P., Berggren, P. O., Bokvist, K., Ericson, H., Moehler, H., Oestenson, C. G., and Smith, P. A. (1989) Glucose-inhibition of glucagon secretion involves activation of GABAA-receptor chloride channels. Nature 341, 233-236.

(17) Xiang, Y.-Y., Wang, S., Liu, M., Hirota, J. A., Li, J., Ju, W., Fan, Y., Kelly, M. M., Ye, B., Orser, B., O’Byrne, P. M., Inman, M. D., Yang, X., and Lu, W.-Y. (2007) A GABAergic system in airway epithelium is essential for mucus overproduction in asthma. Nat. Med. 13, 862-867.

(18) Erdoe, S. L., and Wolff, J. R. (1990) $\gamma$-Aminobutyric acid outside the mammalian brain. J. Neurochem. 54, 363-372.

(19) Baekkeskov, S., Aanstoot, H. J., Christgai, S., Reetz, A., Solimena, M., Cascalho, M., Folli, F., Richter-Olesen, H., and Camilli, P.-D. (1990) Identification of the 64K autoantigen in insulin-dependent diabetes as the GABA-synthesizing enzyme glutamic acid decarboxylase. Nature 347, 151-156.

(20) Kaufman, D. L., Erlander, M. G., Clare-Salzler, M., Atkinson, M. A., Maclaren, N. K., and Tobin, A. J. (1992) Autoimmunity to two forms of glutamate decarboxylase in insulin-dependent diabetes mellitus. J. Clin. Invest. 89, 283-292.

(21) Richter, W., Endl, J., Eiermann, T. H., Brandt, M., KientschEngel, R., Thivolet, C., Jungfer, H., and Scherbaum, W. A. (1992) Human monoclonal islet cell antibodies from a patient with insulindependent diabetes mellitus reveal glutamate decarboxylase as the target antigen. Proc. Natl. Acad. Sci. U. S. A. 89, 8467-8471.

(22) Erlander, M. G., Tillakaratne, N. J. K., Feldblum, S., Patel, N., and Tobin, A. J. (1991) Two genes encode distinct glutamate decarboxylases. Neuron 7, 91-100.

(23) Erlander, M. G., and Tobin, A. J. (1991) The structural and functional heterogeneity of glutamic acid decarboxylase: a review. Neurochem. Res. 16, 215-226.

(24) Legay, F., Pelhate, S., and Tappaz, M. L. (1986) Phylogenesis of brain glutamic acid decarboxylase from vertebrates: immunochemical studies. J. Neurochem. 46, 1478-1486.

(25) Martin, S. C., Heinrich, G., and Sandell, J. H. (1998) Sequence and expression of glutamic acid decarboxylase isoforms in the developing zebrafish. J. Comp. Neurol. 396, 253-266.

(26) Martin, D. L., Liu, H., Martin, S. B., and Wu, S. J. (2000) Structural features and regulatory properties of the brain glutamate decarboxylases. Neurochem. Int. 37, 111-119.

(27) Kaufman, D. L., Houser, C. R., and Tobin, A. J. (1991) Two forms of the $\gamma$-aminobutyric acid synthetic enzyme glutamate decarboxylase have distinct intraneuronal distributions and cofactor interactions. J. Neurochem. 56, 720-723.

(28) Pinal, C. S., and Tobin, A. J. (1998) Uniqueness and redundancy in GABA production. Perspect. Dev. Neurobiol. 5, 109-118.

(29) Esclapez, M., Tillakaratne, N. J. K., Tobin, A. J., and Houser, C. R. (1993) Comparative localization of mRNAs encoding two forms of glutamic acid decarboxylase with nonradioactive in situ hybridization methods. J. Comp. Neurol. 331, 339-362. 
(30) Feldblum, S., Erlander, M. G., and Tobin, A. J. (1993) Different distributions of GAD65 and GAD67 mRNAs suggest that the two glutamate decarboxylases play distinctive functional roles. J. Neurosci. Res. 34, 689-706.

(31) Sheikh, S. N., Martin, S. B., and Martin, D. L. (1999) Regional distribution and relative amounts of glutamate decarboxylase isoforms in rat and mouse brain. Neurochem. Int. 35, 73-80.

(32) Cocco, A., Roennberg, A. M. C., Jin, Z., Andre, G. I., Vossen, L. E., Bhandage, A. K., Thoernqvist, P.-O., Birnir, B., and Winberg, S. (2017) Characterization of the $\gamma$-aminobutyric acid signaling system in the zebrafish (Danio rerio Hamilton) central nervous system by reverse transcription-quantitative polymerase chain reaction. Neuroscience 343, $300-321$.

(33) Varju, P., Katarova, Z., Madarasz, E., and Szabo, G. (2001) GABA signalling during development: new data and old questions. Cell Tissue Res. 305, 239-246.

(34) Katarova, Z., Sekerkova, G., Prodan, S., Mugnaini, E., and Szabo, G. (2000) Domain-restricted expression of two glutamic acid decarboxylase genes in midgestation mouse embryos. J. Comp. Neurol. 424, 607-627.

(35) Condie, B. G., Bain, G., Gottlieb, D. I., and Capecchi, M. R. (1997) Cleft palate in mice with a targeted mutation in the $\gamma$ aminobutyric acid-producing enzyme glutamic acid decarboxylase 67 . Proc. Natl. Acad. Sci. U. S. A. 94, 11451-11455.

(36) Asada, H., Kawamura, Y., Maruyama, K., Kume, H., Ding, R.-G., Kanbara, N., Kuzume, H., Sanbo, M., Yagi, T., and Obata, K. (1997) Cleft palate and decreased brain $\gamma$-aminobutyric acid in mice lacking the 67-kDa isoform of glutamic acid decarboxylase. Proc. Natl. Acad. Sci. U. S. A. 94, 6496-6499.

(37) Culiat, C. T., Stubbs, L. J., Woychik, R. P., Russell, L. B., Johnson, D. K., and Rinchik, E. M. (1995) Deficiency of the $\beta 3$ subunit of the type A $\gamma$-aminobutyric acid receptor causes cleft palate in mice. Nat. Genet. 11, 344-346.

(38) Homanics, G. E., DeLorey, T. M., Firestone, L. L., Quinlan, J. J., Handforth, A., Harrison, N. L., Krasowski, M. D., Rick, C. E., Korpi, E. R., Makela, R., Brilliant, M. H., Hagiwara, N., Ferguson, C., Snyder, K., and Olsen, R. W. (1997) Mice devoid of gamma-aminobutyrate type A receptor beta3 subunit have epilepsy, cleft palate, and hypersensitive behavior. Proc. Natl. Acad. Sci. U. S. A. 94, 4143-4148.

(39) Kanno, K., Suzuki, Y., Yamada, A., Aoki, Y., Kure, S., and Matsubara, Y. (2004) Association between nonsyndromic cleft lip with or without cleft palate and the glutamic acid decarboxylase 67 gene in the Japanese population. Am. J. Med. Genet. 127A, 11-16.

(40) Scapoli, L., Martinelli, M., Pezzetti, F., Carinci, F., Bodo, M., Tognon, M., and Carinci, P. (2002) Linkage disequilibrium between GABRB3 gene and nonsyndromic familial cleft lip with or without cleft palate. Hum. Genet. 110, 15-20.

(41) Deiters, A., and Yoder, J. A. (2006) Conditional Transgene and Gene Targeting Methodologies in Zebrafish. Zebrafish 3, 415-429.

(42) Esengil, H., and Chen, J. K. (2008) Gene regulation technologies in zebrafish. Mol. BioSyst. 4, 300-308.

(43) Shestopalov, I. A., and Chen, J. K. (2008) Chemical technologies for probing embryonic development. Chem. Soc. Rev. 37, 1294-1307.

(44) Nasevicius, A., and Ekker, S. C. (2000) Effective targeted gene "knockdown" in zebrafish. Nat. Genet. 26, 216-220.

(45) Skromne, I., and Prince, V. E. (2008) Current perspectives in zebrafish reverse genetics: moving forward. Dev. Dyn. 237, 861-882.

(46) Tang, X., Maegawa, S., Weinberg, E. S., and Dmochowski, I. J. (2007) Regulating gene expression in zebrafish embryos using lightactivated, negatively charged peptide nucleic acids. J. Am. Chem. Soc. 129, 11000-11001.

(47) Dmochowski, I. J., and Tang, X. (2007) Taking control of gene expression with light-activated oligonucleotides. BioTechniques 43, 161. $163,165,167,169,171$

(48) Tang, X., and Dmochowski, I. J. (2007) Regulating gene expression with light-activated oligonucleotides. Mol. BioSyst. 3, 100110.
(49) Tang, X., and Dmochowski, I. J. (2006) Controlling RNA digestion by RNase $\mathrm{H}$ with a light-activated DNA hairpin. Angew. Chem., Int. Ed. 45, 3523-3526.

(50) Shestopalov, I. A., Sinha, S., and Chen, J. K. (2007) Lightcontrolled gene silencing in zebrafish embryos. Nat. Chem. Biol. 3, 650651.

(51) Ouyang, X., Shestopalov, I. A., Sinha, S., Zheng, G., Pitt, C. L. W., Li, W.-H., Olson, A. J., and Chen, J. K. (2009) Versatile Synthesis and Rational Design of Caged Morpholinos. J. Am. Chem. Soc. 131, 1325513269.

(52) Fedoryak, O. D., and Dore, T. M. (2002) Brominated hydroxyquinoline as a photolabile protecting group with sensitivity to multiphoton excitation. Org. Lett. 4, 3419-3422.

(53) Zhu, Y., Pavlos, C. M., Toscano, J. P., and Dore, T. M. (2006) 8Bromo-7-hydroxyquinoline as a Photoremovable Protecting Group for Physiological Use: Mechanism and Scope. J. Am. Chem. Soc. 128, 42674276.

(54) Tomasini, A. J., Schuler, A. D., Zebala, J. A., and Mayer, A. N. (2009) PhotoMorphs: a novel light-activated reagent for controlling gene expression in zebrafish. Genesis 47, 736-743.

(55) Tallafuss, A., Gibson, D., Morcos, P., Li, Y., Seredick, S., Eisen, J., and Washbourne, P. (2012) Turning gene function ON and OFF using sense and antisense photo-morpholinos in zebrafish. Development 139, 1691-1699.

(56) Deiters, A., Garner, R. A., Lusic, H., Govan, J. M., Dush, M., Nascone-Yoder, N. M., and Yoder, J. A. (2010) Photocaged Morpholino Oligomers for the Light-Regulation of Gene Function in Zebrafish and Xenopus Embryos. J. Am. Chem. Soc. 132, 15644-15650.

(57) Yamazoe, S., Shestopalov, I. A., Provost, E., Leach, S. D., and Chen, J. K. (2012) Cyclic caged morpholinos: conformationally gated probes of embryonic gene function. Angew. Chem., Int. Ed. 51, 69086911.

(58) Wang, Y., Wu, L., Wang, P., Lv, C., Yang, Z., and Tang, X. (2012) Manipulation of gene expression in zebrafish using caged circular morpholino oligomers. Nucleic Acids Res. 40, 11155-11162.

(59) Yamazoe, S., Liu, Q., McQuade, L. E., Deiters, A., and Chen, J. K. (2014) Sequential gene silencing using wavelength-selective caged morpholino oligonucleotides. Angew. Chem., Int. Ed. 53, 10114-10118.

(60) Griepenburg, J. C., Rapp, T. L., Carroll, P. J., Eberwine, J., and Dmochowski, I. J. (2015) Ruthenium-caged antisense morpholinos for regulating gene expression in zebrafish embryos. Chem. Sci. 6, 23422346.

(61) Davis, M. J., Kragor, C. H., Reddie, K. G., Wilson, H. C., Zhu, Y., and Dore, T. M. (2009) Substituent Effects on the Sensitivity of a Quinoline Photoremovable Protecting Group to One- and TwoPhoton Excitation. J. Org. Chem. 74, 1721-1729.

(62) Grone, B. P., and Maruska, K. P. (2016) Three Distinct Glutamate Decarboxylase Genes in Vertebrates. Sci. Rep. 6, 30507.

(63) Lai, F., Fagernes, C. E., Nilsson, G. E., and Jutfelt, F. (2016) Expression of genes involved in brain GABAergic neurotransmission in three-spined stickleback exposed to near-future $\mathrm{CO}_{2}$. Conserv. Physiol. 4, cow068.

(64) Lai, F., Fagernes, C. E., Jutfelt, F., and Nilsson, G. E. (2017) Erratum: Expression of genes involved in brain GABAergic neurotransmission in three-spined stickleback exposed to near-future $\mathrm{CO}_{2}$. Conserv. Physiol. 5, cox004.

(65) MacDonald, R. B., Debiais-Thibaud, M., Talbot, J. C., and Ekker, M. (2010) The relationship between $\mathrm{dlx}$ and gad 1 expression indicates highly conserved genetic pathways in the zebrafish forebrain. Dev. Dyn. $239,2298-2306$.

(66) Higashijima, S.-i., Mandel, G., and Fetcho, J. R. (2004) Distribution of prospective glutamatergic, glycinergic, and GABAergic neurons in embryonic and larval zebrafish. J. Comp. Neurol. 480, 1-18.

(67) Higashijima, S.-i., Schaefer, M., and Fetcho, J. R. (2004) Neurotransmitter properties of spinal interneurons in embryonic and larval zebrafish. J. Comp. Neurol. 480, 19-37.

(68) Asad, N., Deodato, D., Lan, X., Widegren, M. B., Phillips, D. L., Du, L., and Dore, T. M. (2017) Photochemical Activation of Tertiary 
Amines for Applications in Studying Cell Physiology. J. Am. Chem. Soc. 139, 12591-12600.

(69) Asada, H., Kawamura, Y., Maruyama, K., Kume, K., Ding, R.-g., Ji, F. Y., Kanbara, N., Kuzume, H., Sanbo, M., Yagi, T., and Obata, K. (1996) Mice lacking the $65 \mathrm{kDa}$ isoform of glutamic acid decarboxylase (GAD65) maintain normal levels of GAD67 and GABA in their brains but are susceptible to seizures. Biochem. Biophys. Res. Commun. 229, 891-895.

(70) Eisen, J. S., and Smith, J. C. (2008) Controlling morpholino experiments: don't stop making antisense. Development 135, 17351743.

(71) Stainier, D. Y. R., Raz, E., Lawson, N. D., Ekker, S. C., Burdine, R. D., Eisen, J. S., Ingham, P. W., Schulte-Merker, S., Yelon, D., Weinstein, B. M., Mullins, M. C., Wilson, S. W., Ramakrishnan, L., Amacher, S. L., Neuhauss, S. C. F., Meng, A., Mochizuki, N., Panula, P., and Moens, C. B. (2017) Guidelines for morpholino use in zebrafish. PLoS Genet. 13, e1007000.

(72) Joris, M., Schloesser, M., Baurain, D., Hanikenne, M., Muller, M., and Motte, P. (2017) Number of inadvertent RNA targets for morpholino knockdown in Danio rerio is largely underestimated: evidence from the study of Ser/Arg-rich splicing factors. Nucleic Acids Res. 45, 9547-9557.

(73) Ding, R., Tsunekawa, N., and Obata, K. (2004) Cleft palate by picrotoxin or 3-MP and palatal shelf elevation in GABA-deficient mice. Neurotoxicol. Teratol. 26, 587-592.

(74) Hagiwara, N., Katarova, Z., Siracusa, L. D., and Brilliant, M. H. (2003) Nonneuronal expression of the GABA(A) beta3 subunit gene is required for normal palate development in mice. Dev. Biol. 254, 93101.

(75) Zimmerman, E. F., and Wee, E. L. (1984) Role of neurotransmitters in palate development. Curr. Top. Dev. Biol. 19, 37-63.

(76) Wee, E. L., Norman, E. J., and Zimmerman, E. F. (1986) Presence of $\gamma$-aminobutyric acid in embryonic palates of AJ and SWV mouse strains. J. Craniofacial Genet. Dev. Biol. 6, 53-61.

(77) Culiat, C. T., Stubbs, L. J., Woychik, R. P., Russell, L. B., Johnson, D. K., and Rinchik, E. M. (1995) Deficiency of the beta 3 subunit of the type A gamma-aminobutyric acid receptor causes cleft palate in mice. Nat. Genet. 11, 344-346.

(78) Miller, R. P., and Becker, B. A. (1975) Teratogenicity of oral diazepam and diphenylhydantoin in mice. Toxicol. Appl. Pharmacol. 32, $53-61$.

(79) Jurand, A., and Martin, L. V. H. (1994) Cleft palate and open eyelids inducing activity of lorazepam and the effect of flumazenil, the benzodiazepine antagonist. Pharmacol. Toxicol. 74, 228-235.

(80) Wee, E. L., and Zimmerman, E. F. (1983) Involvement of GABA in palate morphogenesis and its relation to diazepam teratogenesis in two mouse strains. Teratology 28, 15-22.

(81) Aarskog, D. (1975) Association between maternal intake of diazepam and oral clefts. Lancet 306, 921.

(82) Safra, M. J., and Oakley, G. P., Jr. (1975) Association between cleft lip with or without cleft palate and prenatal exposure to diazepam. Lancet 306, 478-480.

(83) Saxen, I., and Saxen, L. (1975) Association between maternal intake of diazepam and oral clefts. Lancet 306, 498.

(84) Rosenberg, L., Mitchell, A. A., Parsells, J. L., Pashayan, H., Louik, C., and Shapiro, S. (1983) Lack of relation of oral clefts to diazepam use during pregnancy. N. Engl. J. Med. 309, 1282-1285.

(85) Loescher, W. (1979) 3-Mercaptopropionic acid: convulsant properties, effects on enzymes of the $\gamma$-aminobutyrate system in mouse brain and antagonism by certain anticonvulsant drugs, aminooxyacetic acid and gabaculine. Biochem. Pharmacol. 28, 1397-1407.

(86) Rodriguez de Lores Arnaiz, G., Alberici de Canal, M., Robiolo, B., and Mistrorigo de Pacheco, M. (1973) Effect of the convulsant 3mercaptopropionic acid on enzymes of the $\gamma$-aminobutyrate system in the rat cerebral cortex. J. Neurochem. 21, 615-623.

(87) Leweke, F. M., Louvel, J., Rausche, G., and Heinemann, U. (1990) Effects of pentetrazol on neuronal activity and on extracellular calcium concentration in rat hippocampal slices. Epilepsy Res. 6, 187198.
(88) Baraban, S. C., Taylor, M. R., Castro, P. A., and Baier, H. (2005) Pentylenetetrazole induced changes in zebrafish behavior, neural activity and c-fos expression. Neuroscience 131, 759-768.

(89) Tao, L., Lauderdale, J. D., and Sornborger, A. T. (2011) Mapping Functional Connectivity between Neuronal Ensembles with Larval Zebrafish Transgenic for a Ratiometric Calcium Indicator. Front. Neural Circuits 5, 2.

(90) Dhir, A. (2012) Pentylenetetrazol (PTZ) kindling model of epilepsy. Curr. Protoc. Neurosci. 58, 9.37.31-39.37.12.

(91) Hewapathirane, D. S., Dunfield, D., Yen, W., Chen, S., and Haas, $\mathrm{K}$. (2008) In vivo imaging of seizure activity in a novel developmental seizure model. Exp. Neurol. 211, 480-488.

(92) Livingston, R. (1971) Behavior of Photochromic Systems. In Photochromism (Brown, G. H., Ed.), pp 13-44, Wiley, New York.

(93) Hatchard, C. G., and Parker, C. A. (1956) A new sensitive chemical actinometer. II. Potassium ferrioxalate as a standard chemical actinometer. Proc. R. Soc. London, Ser. A 235, 518-536.

(94) Westerfield, M., Ed. (2007) The Zebrafish Book: A Guide for the Laboratory Use of Zebrafish (Danio rerio), 5th ed., University of Oregon Press, Eugene, OR.

(95) Kimmel, C. B., Ballard, W. W., Kimmel, S. R., Ullmann, B., and Schilling, T. F. (1995) Stages of embryonic development of the zebrafish. Dev. Dyn. 203, 253-310.

(96) Sun, Y., Wloga, D., and Dougan, S. T. (2011) Embryological manipulations in zebrafish. Methods Mol. Biol. 770, 139-184.

(97) Bill, B. R., Petzold, A. M., Clark, K. J., Schimmenti, L. A., and Ekker, S. C. (2009) A Primer for Morpholino Use in Zebrafish. Zebrafish 6, 69-77.

(98) Jutkiewicz, E. M., Baladi, M. G., Folk, J. E., Rice, K. C., and Woods, J. H. (2006) The convulsive and electroencephalographic changes produced by nonpeptidic $\delta$-opioid agonists in rats: comparison with pentylenetetrazol. J. Pharmacol. Exp. Ther. 317, 1337-1348.

(99) Peterson, R. T., and Fishman, M. C. (2004) Discovery and use of small molecules for probing biological processes in zebrafish. Methods Cell Biol. 76, 569-591.

(100) Trapani, J. G., and Nicolson, T. (2010) Physiological recordings from zebrafish lateral-line hair cells and afferent neurons. Methods Cell Biol. 100, 219-231.

(101) Nüsslein-Volhard, C., and Dahm, R., Eds. (2002) Zebrafish: A Practical Approach, Oxford University Press, Oxford, UK.

(102) Harlow, E., and Lane, D. (1988) Antibodies: A Laboratory Manual, Cold Spring Harbor Laboratory Press, Cold Spring Harbor, NY.

(103) Sambrook, J., and Russell, D. W. (2001) Molecular Cloning: A Laboratory Manual, Cold Spring Harbor Laboratory Press, Cold Spring Harbor, NY.

(104) Bradford, M. M. (1976) A rapid and sensitive method for the quantitation of microgram quantities of protein utilizing the principle of protein-dye binding. Anal. Biochem. 72, 248-254.

(105) Kimmel, C. B., Miller, C. T., Kruze, G., Ullmann, B., BreMiller, R. A., Larison, K. D., and Snyder, H. C. (1998) The Shaping of Pharyngeal Cartilages during Early Development of the Zebrafish. Dev. Biol. 203, 245-263.

(106) Schneider, C. A., Rasband, W. S., and Eliceiri, K. W. (2012) NIH Image to ImageJ: 25 years of image analysis. Nat. Methods 9, 671675 . 